\title{
Evaluation of Repositioning in Pressure Ulcer Prevention
}

\author{
Ulrika Källman
}

\author{
Division of Nursing Science \\ Department of Medical and Health Sciences \\ Linköping University, Sweden
}

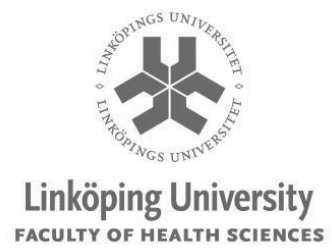

Linköping 2015 
@Ulrika Källman, 2015

Cover picture/illustration: Maja Modén

Published articles have been reprinted with the permission of the copyright holders

Printed in Sweden by LiU-Tryck, Linköping, Sweden, 2015

ISBN 978-91-7519-095-2

ISSN 0345-0082 
To my family

Lennart, Oscar and Eric 



\section{CONTENTS}

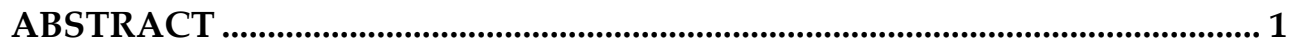

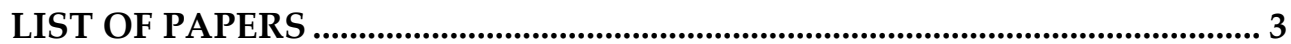

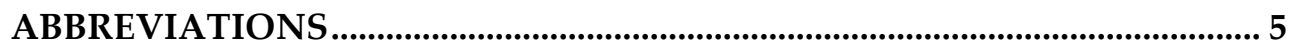

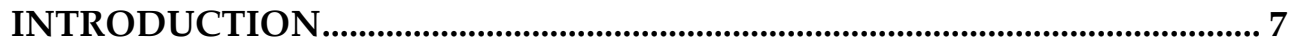

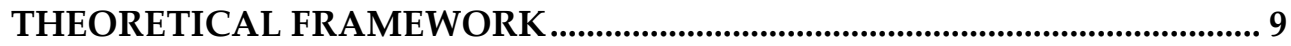

Pressure ulcer prevention.................................................................................... 9

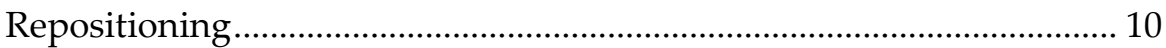

A holistic approach to repositioning patients ............................................... 12

Microcirculation ..................................................................................................... 13

Anatomy and physiology of microcirculation ......................................... 13

Blood flow responses related to loading ................................................... 15

Blood flow responses among elderly patients in different positions.... 17

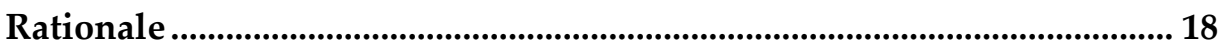

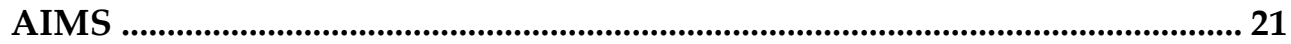

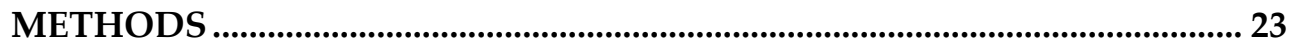

Design and settings ................................................................................ 23

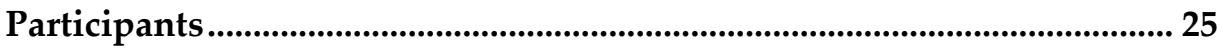

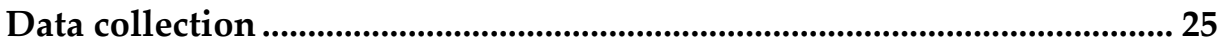

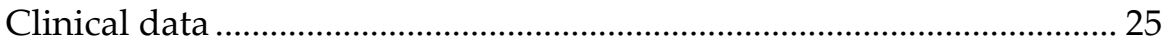

Measurements...................................................................................................... 27

Patients spontaneous movements .......................................................... 27

Blood flow, interface pressure, and skin temperature ………………...... 28

Other measurements ................................................................................. 30

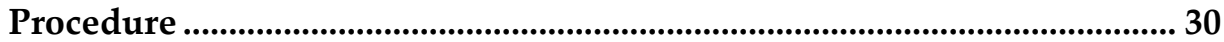

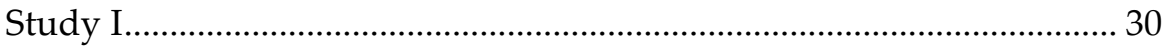

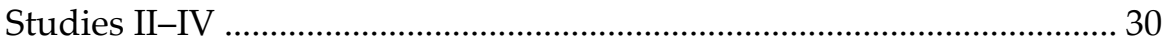




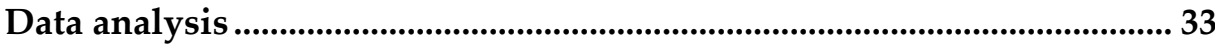

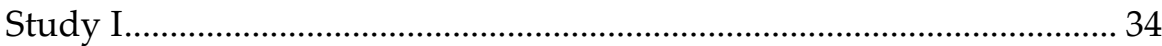

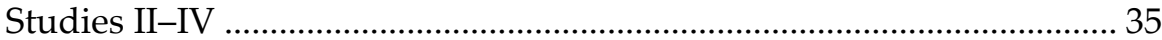

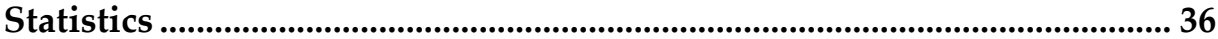

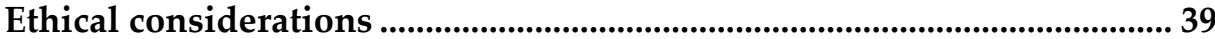

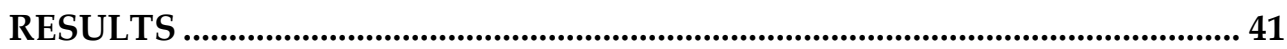

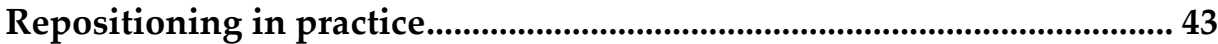

Nursing staff-induced repositioning ...................................................... 43

Patient spontaneous movements................................................................ 45

The effects of different lying positions ............................................................. 47

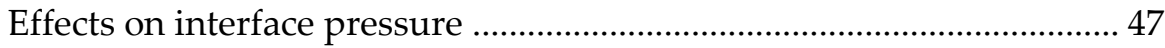

Effects on skin temperature................................................................... 47

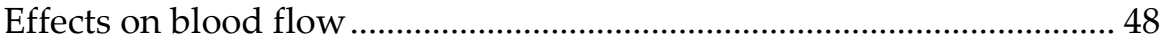

Variables with effects on tissue blood flow during load .......................... 52

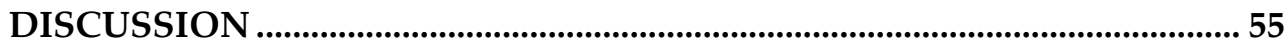

Repositioning in practice …………….................................................. 55

Evaluation of different lying positions ..................................................... 57

Blood flow patterns during and after load .................................................. 59

Methodological considerations ............................................................................ 61

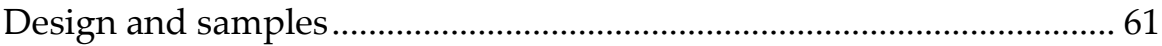

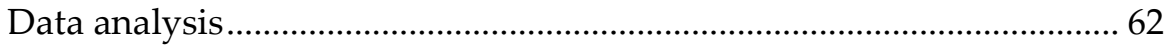

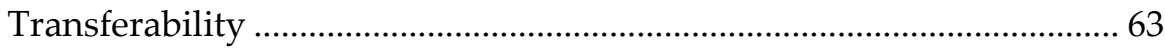

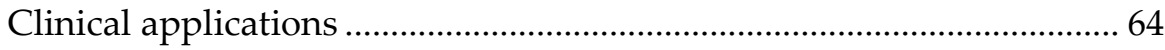

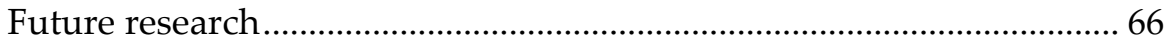

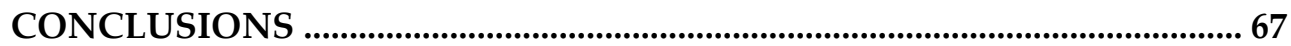

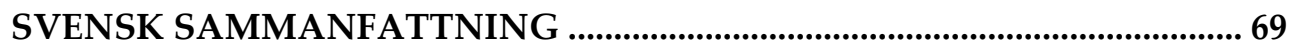

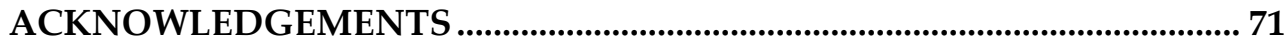

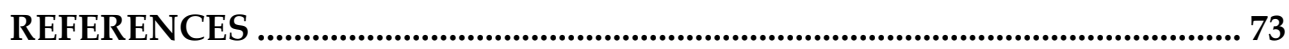




\section{ABSTRACT}

Introduction: To reduce the risk for pressure ulcers, repositioning of immobile patients is an important standard nursing practice. However, knowledge on how this preventive intervention is carried out among elderly immobile patients is limited. Furthermore, to what extent patients perform minor movements between nursing staff-induced repositionings is largely unknown, but these movements might have implications for the repositioning intervention. Different lying positions are used in repositioning schedules, but there is lack of evidence to recommend specific positions.

Aim: The overall aim of this thesis was to describe and evaluate how repositioning procedures work in practice in the care of elderly immobile patients. The aim was also to compare the effects of different positions with regard to interface pressure, skin temperature, and tissue blood flow in elderly patients lying on a pressure-redistribution mattress.

Methods: This thesis consists of four quantitative studies. In Study I, 62 elderly immobile patients were included. All movements the patients made, either with help from the nursing staff or spontaneously, were registered continuously over the course of three days using the MovinSense monitoring system. The nursing staff documented each time they repositioned the patients, and the movements registered by MiS were compared with the nursing staff notes to identify the spontaneous movements. Study II served to pilot the procedure for Study III. Tissue blood flow and skin temperature were measured in hospital patients $(n=20)$ for 5 minutes over the sacrum, the trochanter major, and the gluteus muscle in two supine, two semi-Fowler, and two lateral positions. In Study III, a new sample was recruited $(n=25)$ from three nursing homes. Measurement of interface pressure was added, and the measurements were extended from 5 minutes to 1 hour. The six positions were reduced to four by excluding the two semi-Fowler positions. Blood flow was measured using non-invasive optical techniques including photopletysmography (Study II-IV) and laser Doppler flowmetry (Studies III and IV). In Study IV a deeper analysis of the individual pressure-induced vasodilation (PIV) responses was performed on the sample from Study III. An age of 65 years or older was an inclusion criterion in all studies.

Results: Study I showed that there was a large variation in the extent to which the elderly immobile patients made spontaneous movements, and these movements were positively related to taking analgesics and negatively related 
to taking psycholeptics. Several factors were related to the frequency with which the nursing staff repositioned the patients, and the risk assessment score had the highest impact; patients scored as high risk for pressure ulcer development were repositioned more frequently than patients scored as low risk. However, the spontaneous movement frequency was not associated with any risk scores. Study II showed that the different lying positions influenced the blood flow in different ways and that the study design and procedure worked well. In Study III, it was found that the interface pressure was significantly higher in the $0^{\circ}$ supine and $90^{\circ}$ lateral position, compared to the $30^{\circ}$ supine tilt and $30^{\circ}$ lateral positions. It was also found that the overall blood flow response during one hour of loading, was significantly higher in the $30^{\circ}$ supine tilt position than in the $0^{\circ}$ supine, $30^{\circ}$ lateral, and $90^{\circ}$ lateral positions. The overall blood flow in the $90^{\circ}$ lateral position did not differ compared to the $30^{\circ}$ lateral position. The most common pattern at the group level in Studies II and III was an increase in median blood flow during load irrespective of position and tissue depth. However, in patients lacking a PIV response (Study IV), the blood flow decreased immediately and remained below baseline during the one hour of loading.

Conclusion: Although elderly and immobilised, some patients frequently perform minor movements while others do not. Patients who cannot perform minor movements are important for the nursing staff to identify because they very likely need more intensive repositioning interventions. The spontaneous movement frequency was not associated with the risk assessment score, and this implies that some immobile patients assessed as low risk might need to be repositioned as often as patients assessed as high risk. Of the positions evaluated, the $30^{\circ}$ supine tilt position was concluded to be most beneficial and might thus be a valuable position to use in a repositioning schedule. The results show further that there was no great difference in how the blood flow was affected in the $90^{\circ}$ lateral position compared to the $30^{\circ}$ lateral position, which question the appropriateness of the recommendation to avoid the $90^{\circ}$ lateral position. The patients with lacking a PIV response might be particularly vulnerable to pressure, which also implies that these patients might need to be repositioned more frequently. However, these patients are not easily identified, and further studies are needed.

Keywords: Elderly patient, Immobility, Interface pressure, Patient repositioning, Pressure ulcer, Prevention, Risk assessment, Skin temperature, Tissue blood flow 


\section{LIST OF PAPERS}

This thesis is based on the following papers, which will be referred to by their roman numerals.

I. Nursing staff induced repositionings and immobile patients' spontaneous movements in nursing care. Ulrika Källman, Sara Bergstrand, Anna-Christina Ek, Maria Engström, Margareta Lindgren. International Wound Journal 2015; Mar 16. [Epub ahead of print]

II. Different lying positions and their effects on tissue blood flow and skin temperature in older adult patients. Ulrika Källman, Sara Bergstrand, Anna-Christina Ek, Maria Engström. Lars-Göran Lindberg, Margareta Lindgren. Journal of Advanced Nursing 2013; 69(1):133-144.

III. The effect of different lying positions on interface pressure, skin temperature, and tissue blood flow in nursing home residents. Ulrika Källman, Maria Engström, Sara Bergstrand, Anna-Christina Ek, Mats Fredrikson, Lars-Göran Lindberg, Margareta Lindgren. Biological Research for Nursing 2015;17(2):142-51.

IV. Sacral pressure-induced blood flow responses at different tissue depths during one hour supine bedrest in nursing home residents. Ulrika Källman, Sara Bergstrand, Anna-Christina Ek, Maria Engström, Margareta Lindgren. Submitted.

Published articles have been reprinted with the permission of the copyright holder. 



\section{ABBREVIATIONS}

BMI Body Mass Index

EPUAP European Pressure Ulcer Advisory Panel

LDF Laser Doppler Flowmeter

NPUAP National Pressure Ulcer Advisory Panel

MiS MovinSense - a microelectronic device developed to monitor and document patients' movements

MOV Number of spontaneous movements by the patient

PIV Pressure-induced vasodilation

PPG Photoplethysmography

RAPS Risk Assessment Pressure ulcer Scale

REP Number of nursing staff-induced repositionings 



\section{INTRODUCTION}

Pressure ulcers are a worldwide problem affecting both hospital and community populations. Studies have shown that the development of pressure ulcers is related to the patient's ability to move or change position, and highrisk groups include disabled patients and elderly persons with comorbidities (Coleman et al., 2013; Lindgren et al., 2004). Pressure ulcers are often preventable and are thus regarded as harms according to the Swedish patient safety law (2010:659). Despite efforts to prevent pressure ulcers, they are still common. In Sweden, the prevalence of pressure ulcers has been shown to be $16 \%$ among hospital inpatients and 12\% among nursing home residents (Bååth et al., 2014). In other European countries, a prevalence of pressure ulcers of $7 \%$ to $18 \%$ has been found among hospital inpatients (Bredesen et al., 2015; Kottner et al., 2010; Vanderwee et al., 2011) and a prevalence of $4 \%$ to $16 \%$ has been found among nursing home residents (Fossum et al., 2011; Kottner et al., 2010; Moore \& Cowman, 2012).

For the individual patient, a pressure ulcer means suffering, and the presence of the ulcer affects the patient's quality of life in many different ways (Gorecki et al., 2009). Pain, dependency, isolation, depression, and anxiety are common experiences related to having such wounds. The impact of pain is significant, it is often constant, and it can be exacerbated by dressing changes and by the pressure redistribution equipment used or by movements (Hopkins et al., 2006). Further, the pressure ulcer can disrupt rehabilitation, increase hospital stays, and result in lengthy treatments (Spilsbury et al., 2007).

In addition to the burden and suffering that the pressure ulcers cause the patient, these ulcers are associated with substantial health-care costs. Estimates in The Netherlands put the costs for pressure ulcer treatment between $€ 174.5$ and $€ 178.8$ million per year (Schuurman et al., 2009), and in the UK they are estimated to cost $£ 0.4-£ 2.1$ billion annually, which in 2004 was $4 \%$ of the total national health services expenditure (Bennett et al., 2004). Nursing time dominates the total cost, while the cost of materials for dressing wounds and pressure relief contributes to a lesser extent. In Sweden, a category 1 pressure ulcer has been estimated to cost the hospital care approximately 8000 SEK per ulcer and a category 4 approximately 47,500 SEK per ulcer (Björstad \& Forsmark, 2012). These figures include only nursing time and materials for local wound treatment. The cost increases according to the severity of the pressure 
ulcer due to complications and/or prolonged hospital stay (Bennett et al., 2004; Filius et al., 2013).

For the patients and the health care system, it is of great value if pressure ulcers can be prevented. In recent years, much attention has been paid to implementing routines for risk assessment and skin assessment in both hospital and community care to provide early identification of patients who are at risk of developing pressure ulcers and to carry out preventive measures.

Because prolonged pressure exposure of the soft tissue is the primary cause of pressure ulcers, pressure relief is an essential preventive intervention. Thus, alongside the use of pressure redistribution mattresses and cushions, regular repositioning are a measure recommended for immobile patients (NPUAP et al., 2014) and commonly used in standard nursing practice (Källman \& Suserud, 2009; Voz et al., 2011). However, the current evidence to support specific repositioning regimes is still weak. Some randomized controlled studies have been performed to evaluate different repositioning frequencies and positions, but high levels of bias and low statistical power make it difficult to draw conclusions from these studies (Gillespie et al., 2014; Moore \& Cowman, 2015). Different time frames and different positions have also been evaluated in laboratory settings, but these have mainly used animals or healthy young adults as test persons, which makes it difficult to transfer the results to nursing practice. There is lack of knowledge on how repositioning as prevention works in practice, and there is a lack of research comparing tissue responses during loading in different positions in a clinical setting. This thesis contributes with knowledge in this field based on an elderly patient population. 


\section{THEORETICAL FRAMEWORK}

\section{Pressure ulcer prevention}

A pressure ulcer is defined as "a localized injury to the skin and/or the underlying tissue, usually over a bony prominence, as a result of pressure, or pressure in combination with shear" (NPUAP et al., 2014). According to the European and National Pressure Ulcer Advisor Panels (EPUAP and NPUAP, respectively) classification system, category 1 pressure ulcers are defined as a nonblanchable erythema, category 2 as a partial thickness loss of the dermis, category 3 as fullthickness skin loss, and category 4 as full-thickness tissue loss. Unstageable and suspected deep tissue injuries are additional categories incorporated into the classification system and are equal to category 4 in severity (NPUAP. et al., 2014).

Although pressure and shear forces are considered the most causative factors of these ulcers, other extrinsic factors such as heat accumulation between the patient and the bed, friction, and humidity are other important contributing factors. Furthermore, there are numerous intrinsic factors that affect the ability of the patient's skin to resist pressure and shear forces, including skin condition, age, nutrition, level of mobility and activity, body temperature, incontinence (moisture), peripheral vascular disease, blood pressure, haematological measures, general physical condition, and sensory perception (Coleman et al., 2013; Fogerty et al., 2008). In geriatric patient populations, the presence of existing pressure ulcers has also emerged as an important risk factor for further pressure ulcer development (Baumgarten et al., 2006). However, no single factor can explain pressure ulcer risk, and it appears that it is a complex interplay of numerous factors that increases the probability of pressure ulcer development (Coleman et al., 2013).

To avoid pressure ulcers in clinical practice, it is important to identify patients who are at risk and to initiate prevention interventions for them. Thus, risk assessment in nursing care is considered the cornerstone to pressure ulcer prevention (Coleman et al., 2014). One recommendation is to perform systematic risk assessments using a risk assessment scale in addition to clinical judgment (NPUAP et al., 2014). Many such scales have been developed since the early 1960s and they all seek to summarize a selection of intrinsic and extrinsic factors known to contribute to ulceration. The total scores on these 
scales are related to cut-off levels that indicate the presence or absence of a risk for pressure ulcer development. However, due to the complex interactions between risk factors, it is difficult to use the total score to develop individualized prevention plans. Instead, it is suggested to use the total score as an alert signal of risk and to use the subscale scores to plan patient-specific interventions (Tescher et al., 2012).

Preventive interventions are purposeful actions to help the patient retain, attain, and/or maintain system stability (Fawcett, 1995; Neuman, 1996). These can involve avoiding risk factors or by strengthening the patient's ability to deal with these risk factors when they are encountered. The interventions can be carried out at the primary, secondary, or tertiary level. In the context of pressure ulcers, primary prevention is carried out when a pressure ulcer risk is suspected or identified and the goal of the interventions is to retain undamaged tissue. At the secondary level the skin and/or the underlying tissue has been broken and a pressure ulcer has occurred. At this level, the interventions are undertaken to prevent worsening of the ulcer, to attain wound healing, and to prevent additional ulcers. At the tertiary level, the pressure ulcer is healed and the prevention interventions focus on maintaining intact tissue by strengthening the patient's resistance to risk factors known to be hazardous for the patient. This process circles back to the primary prevention level. Several interventions are available to prevent pressure ulcers, including various support surfaces, repositioning and mobilization, skin care, and nutritional supplementations (Chou et al., 2013). A mix of these interventions is often required at all levels of pressure ulcer prevention.

\section{Repositioning}

Even though numerous different factors lead to the development of pressure ulcers, immobility is regarded as the primary intrinsic risk factor (Coleman et al., 2013; Lindgren et al., 2004). The theory behind this is that pressure from lying or sitting on a particular part of the body can result in sustained deformation of soft tissues and a reduction in blood flow to the specific area. Under normal circumstances, this would result in pain and discomfort that would stimulate the person to change position, both when they are awake and asleep (De Koninck et al., 1992). However, if the person is unable to reposition himself or herself, or has impaired sensory perception and does not feel the discomfort, a failure to reposition might ultimately cause ischemia and 
subsequent tissue damage (Kosiak, 1959; Loerakker et al., 2011) A clear relationship has been shown between pressure ulcer development and the number of the spontaneous nocturnal movements that elderly patients make (Exton-Smith \& Sherwin, 1961). Patients who repositioned themselves 50 or more times during the night had no pressure ulcers, whereas $90 \%$ of patients who moved themselves 20 times or less developed ulcers.

Thus, with the aim of relieving or redistributing the pressure and reducing the risk of pressure ulcers, repositioning patients who are immobile is an important nursing intervention. Traditionally, it has been emphasized that repositioning should be carried out at least every two hours. This was mainly based on animal research performed by Kosiak (1959) who found tissue damage after 1-2 hours of high pressure exposure in dogs. The two-hour interval has for a long time been common practice, but in today's nursing practice the interval has increased (Vanderwee et al., 2007). More recent clinical research has concluded that the interval might be prolonged to every 3-4 hours when pressure-redistribution mattresses are used (Bergstrom et al., 2013), but the evidence for recommending time intervals is still sparse (Gillespie et al., 2014). Furthermore, in studies on repositioning, some patients have been shown to undertake spontaneous movements between the scheduled repositionings (Vanderwee et al., 2007; Young, 2004). This might influence the intervention but, perhaps more importantly, might also indicate a need for more frequent repositioning in those who are unable to undertake spontaneous movements themselves (Sprigle \& Sonenblum, 2011). To what extent patients who are immobilized do or do not undertake spontaneous movements between nursinginduced repositioning shifts are largely unknown.

When repositioning patients, an alternation between supine and lateral positions is often used. Based on the reasoning that high pressure causes pressure ulcers, it is suggested that the $90^{\circ}$ lateral position, which causes high pressure over the trochanter major, should be avoided. Instead, when a lateral position is required, the $30^{\circ}$ lateral position is preferable (NPUAP et al., 2014). It has been shown in laboratory studies that this position reduces interface pressure over bony prominences (Defloor, 2000) and thus allows higher tissue perfusion (Colin et al., 1996; Seiler et al., 1986). Such laboratory work appears to have influenced clinical practice because the $30^{\circ}$ lateral position is commonly recommended in guidelines. However, patients do not always feel comfortable in this position in bed, and this is a significant problem (Young, 2004). Additionally, this position is difficult to maintain as the patient moves in the bed (Vanderwee et al., 2007). While in a supine position, a so-called $30^{\circ}$ supine tilt position is sometimes used, as is the $30^{\circ}$ lateral position, with the aim of 
transferring pressure over the bony prominences (here the sacrum) to larger tissue masses (here the gluteus maximus muscle). In the $30^{\circ}$ supine tilt position, two triangle-shaped wedges are used to create the necessary $30^{\circ}$ angle. The wedges are placed under the mattress while the patient is still lying on his/her back. However, this technique has not yet been evaluated in reducing pressure ulcers.

\section{A holistic approach to repositioning patients}

Although repositioning is often associated with pressure ulcer prevention, it is also important for minimising spasticity, promoting sensory awareness, stimulating orientation to the environment and body image awareness, and minimising respiratory and vascular complications (Hawkins et al., 1999). However, the positioning strategies used to prevent complications related to immobility are in some cases conflicting. For instance, to facilitate breathing and/or prevent aspiration and ventilator-associated pneumonia, it is recommended to maintain an elevation of the bed at $30^{\circ}$ or higher, i.e. a semiFowler position (Burk \& Grap, 2012). In contrast, to prevent pressure ulcers it is recommended to not increase the head of the bed more than $30^{\circ}$ so as to minimize the pressure and shear forces over the sacrum and coccyx (NPUAP et al., 2014). Although some of the shear forces can be counteracted by raising the foot of the bed or by bending the knees while in a semi-Fowler position, this might not reduce the pressure on the sacral area (Harada et al., 2002). A further example is the conflict in using the $90^{\circ}$ lateral position. Moving into this position is beneficial for lung function (Ross \& Dean, 1989) and is important for many neurological patients for the control of muscle tone (Hawkins et al., 1999), but, as highlighted above, it is a position that carries a risk for pressure ulcer development because of the high interface pressure that it puts on the trochanter major (Defloor, 2000; NPUAP et al., 2014).

Furthermore, one must consider that repositioning can be painful, might worsen nausea or vomiting, and can be contraindicated due to hemodynamic instability and that some patients are not able to lie in certain positions (Langemo, 2012). Frequent repositioning might also cause sleep fragmentation, which is well known to have negative effects on immune function and recovery (Singer \& Applebee, 2008). It can be concluded that numerous factors need to be taken in account when planning a patient's repositioning schedule, and recently published guidelines do not actually recommend a specific time 
interval (NPUAP et al., 2014). Instead, these guidelines state that repositioning frequency should be based on professional judgment that takes into account the patient's tissue tolerance, level of activity and mobility, medical condition, treatment plan, support surface, and comfort. In today's nursing care, an increasingly common practice is to have individually planned schedules with a variety of time intervals (Båath et al., 2014), and this might be considered more of a holistic approach.

\section{Microcirculation}

As mentioned above, failure to reposition oneself might ultimately cause localized ischemia as a result of sustained deformation of the soft tissue. The ischemia leads to hypoxia, decreased nutrient supply, and accumulation of waste products and, if prolonged, might cause tissue inflammation, thrombus formation, oedema, and cell death (Kosiak, 1959; Witkowski \& Parish, 1982). This is the most established theory of pressure ulcer aetiology whereby mechanical loading leads to tissue breakdown. Other theories have been proposed, including impaired lymphatic function (Reddy et al., 1981), ischemiareperfusion injury (Peirce et al., 2000), and, more recently, sustained deformations of cells causing cell-membrane leakage (Leopold \& Gefen, 2013; Shoham \& Gefen, 2012). Among these theories, it is suggested that cell deformation is mainly involved over short periods (within minutes) with highpressure exposure, while ischemia increases over time, such as several hours, and becomes the dominant factor for prolonged pressure exposure (Stekelenburg et al., 2008). In clinical practice, where at-risk patients are often exposed to prolonged loading on a supporting and pressure-redistributing surface, it might be most likely that ischemia plays the major role in the damage process. Thus, based on the ischemia theory, this thesis focuses on how microcirculation, i.e. blood flow in the skin and underlying tissue, is affected by loading in situations related to repositioning.

\section{Anatomy and physiology of microcirculation}

The microcirculation consists of vessels smaller than $100 \mu \mathrm{m}$ in diameter and is organized into arterioles, capillaries, and venules. This network supplies 
the tissues and organs with oxygen and nutrients, carries away metabolic waste products, and promotes the immune system (Guyton \& Hall, 2011). In the skin, the microcirculation also plays a major part in the regulation of blood pressure, body temperature, and the distribution of blood volume (Ryan, 1991). The arterioles consist of an endothelial layer surrounded by the internal elastic lamina and a multi-layered smooth muscle coat, and their function is to regulate blood flow through contraction and relaxation. The capillaries consist of a thin endothelial wall with no smooth muscle cells and are primarily responsible for exchange between blood and tissue. The venules also have a thin layer of endothelial cells, but in comparison to arterioles smooth muscles are absent in vessels under $30 \mu \mathrm{m}$ in diameter. The venules drain blood from the capillaries and generally run parallel to the arterioles. They are important for post-capillary vascular resistance, thermoregulation, and immunological defence (Guyton \& Hall, 2009).

The topography of the microcirculation in the skin is slightly different from other organs or tissues. The vessels involved in skin microcirculation are organized into two horizontal plexuses (Figure 1); the upper plexus is situated approximately $1 \mathrm{~mm}$ below the skin surface in the upper dermis and the deep plexus is found in the lower dermis-subcutaneous interface (Johnson et al., 2014). From the upper plexus, an arcade of capillary loops rises up to each dermal papilla. The papillary loops represent the nutritive component of the skin circulation, and the upper plexus is the main thermal regulator. The deep plexus is formed by perforating vessels from the underlying muscles and subcutaneous fat (Braverman, 1997). The two plexuses are connected to each other by ascending arterioles and descending venules. Arterio-venous anastomoses are also found in the skin, especially in the upper dermis, and these allow for faster inflow into the veins without

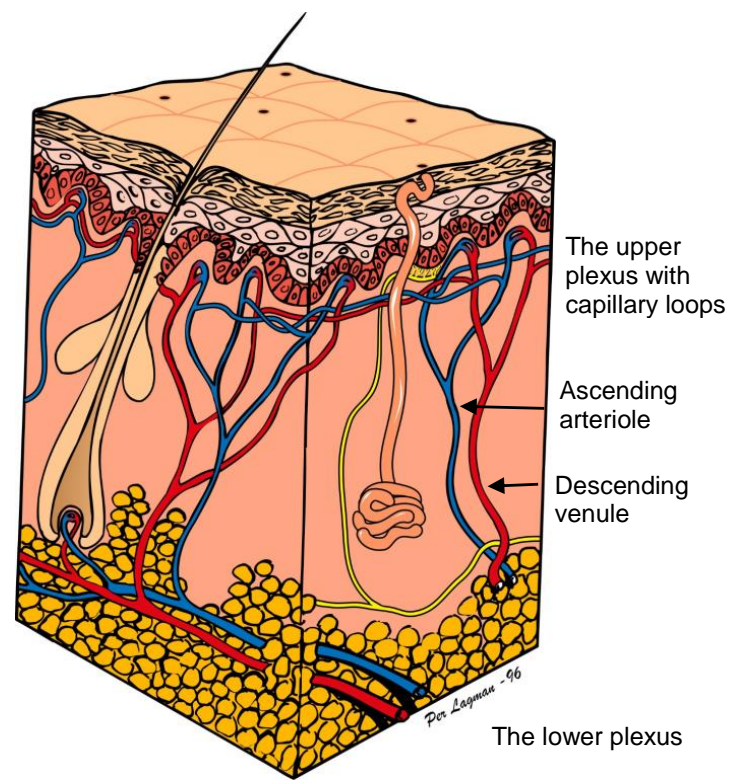

Figure 1. Illustration of the microcirculation in the dermis; the upper and lower plexus. Published with permission from Per Lagman/Media Center TVB $A B$ 
passage through the capillary network (Jonsson, 2008; Sonksen \& Craggs, 1999).

At rest, the arterial vasculature has a vasoconstricted state, known as "vascular tone". Different stimuli, such as increased temperature, metabolism, and pressure, can cause vasodilation of the vessels. When the vessels dilate, the blood flow increases due to a decrease in vascular resistance. This response is regulated by factors released from endothelial cells, hormones, and neural factors and can be localized to a specific organ or can be systemic. Vasodilation is a function of the normal endothelium mainly through the secretion of nitric oxide, prostacyclin, and endothelial-derived hyperpolarizing factors. The loss of normal endothelial function results in impaired vasodilation, and this can be seen in diseases such as diabetes, arteriosclerosis, infection, and renal dysfunction (Giles et al., 2012). Abnormal endothelial function can also be associated with chronological aging mainly due to vascular smooth muscle hypertrophy, loss of connective tissue cells, and degeneration of nerve endings (Johnson et al., 2014; Ryan, 1991).

\section{Blood flow responses related to loading}

Under normal conditions, when tissue is exposed to non-noxious pressure the cutaneous microvessels dilate and the blood flow increases. This phenomenon is referred to as pressure-induced vasodilation (PIV) and is regarded to be a preventive response to minimize the damaging effect of pressure by delaying the occurrence of ischemia (Fromy et al., 2012; Roustit \& Cracowski, 2013). The absence of PIV leads to a decrease in blood flow even in response to low levels of pressure, and this makes the individual vulnerable to externally applied pressure. The PIV function has been shown to be altered in diabetic patients (Koïtka et al., 2004) and in the elderly (Bergstrand et al., 2014; Fromy et al., 2010), but a lack of PIV response can also be found in young, healthy individuals (Bergstrand et al., 2014). With progressively increasing pressure to the skin, the PIV response has been shown to reach its maximum at pressure levels of 25-50 mmHg in young, healthy individuals (Fromy et al., 2010; Schubert \& Fagrell, 1989). At higher pressure levels, the blood flow starts to decrease and with enough pressure the blood flow will finally cease (Johansson et al., 2002; Schubert \& Fagrell, 1989). However, at what pressure threshold the blood flow ceases varies significantly depending on anatomy, bony structures under the area of interest, the amount of deformation that occurs, tissue stiffness, and other individual characteristics, (Bergstrand et al., 2010; Sprigle \& Sonenblum, 
2011). In young, healthy persons in a seated position, pressure up to $120 \mathrm{mmHg}$ has shown to be required for blood flow cessation, but pressure as low as 20-30 $\mathrm{mmHg}$ could be enough to generate the same response among geriatric patients (Bennett et al., 1981).

Because ischemia can arise from any condition when the oxygen demand of the tissue is greater than the supply, there does not need to be a period of total occlusion for ischemia to occur (Rhoades \& Bell, 2009). This might, for instance, be evident in situations of heat accumulation in the skin surface or in case of raised body temperature because a $1{ }^{\circ} \mathrm{C}$ rise in temperature increases metabolism by about $10 \%$ (Guyton \& Hall, 2011). Increased heat in combination with a lack of PIV response might thus lead to ischemia even though the blood flow has not ceased. A recent laboratory study in a healthy adult population has also shown that both pressure and skin temperature independently contribute to ischemia (Lachenbruch et al., 2015). In fact, it was shown that a $1{ }^{\circ} \mathrm{C}$ rise in temperature contributed to a similar ischemic response as $14 \mathrm{mmHg}$ pressure. This further supports the notion that tissue can become more susceptible to ischemia when heat accumulation is present over sustained periods of loading.

A typical sign that the tissue has been ischemic is a rapid increase in blood flow when the pressure is relieved. This phenomenon - called reactive hyperaemia - serves to restore the normal metabolic state of the tissue as quickly as possible and normally lasts from $50 \%$ to $75 \%$ of the total ischemic period (Bliss, 1993; Popcock \& Richards, 2006). As with PIV, the reactive hyperaemia function has been shown to be altered in the elderly (McLellan et al., 2009).

Although reactive hyperaemia is a vital response for tissue recovery, the reperfusion can aggravate tissue damage mainly due to the overproduction and release of oxygen free radicals that are toxic to cells. This harmful side effect of reactive hyperaemia forms the basis of the reperfusion-injury theory (Kasuya et al., 2014; Peirce et al., 2000).

The duration for which skin and muscle cells can tolerate ischemia without damage differs. For example, muscle tissue is more susceptible to damage than skin tissue due to the higher metabolism in muscles (Dinsdale, 1974; Nola \& Vistnes, 1980). Furthermore, internal stress and strains are substantially higher in soft tissues adjacent to bony prominences than soft tissues near the surface, and these bony surfaces have the potential to cause damage in the deep tissue before damage occurs in the superficial tissue. This bottom-to-top pathway underlies the theory of deep tissue injury, which is suggested to be caused by a combination of cell deformation and ischemia (Bliss, 1993; Stekelenburg et al., 2008). 


\section{Blood flow responses among elderly patients in different positions}

Immobile elderly patients are at particularly high risk for pressure ulcer development. With advanced age, the skin becomes more vulnerable to pressure and shear due to loss of connective tissue cells, nerve endings, and blood vessels (Bliss, 1993). In addition, with advanced age the papilla become more flattened as the epidermis gradually thins and reduces the skin's resistance to shearing forces (Stephen-Haynes, 2012). It is clear that blood flow responses such as PIV, vasodilation due to heat stress, and reactive hyperaemia tend to be significantly altered among the elderly (Ek et al., 1984; McLellan et al., 2009), but research on how blood flow responses among the elderly are affected by loading in different positions and over prolonged time is limited.

Schubert and Heraud (1994) measured sacral skin blood flow with laser Doppler flowmeter over the course of 30 minutes in a $0^{\circ}$ supine position and a $45^{\circ}$ semi-Fowler position in two geriatric patient groups; one group had no or low risk for pressure ulcer development, and one group had high risk. The blood flow increased during load in the low-risk group with a mean of $35 \%$ compared to baseline in the $0^{\circ}$ supine position and $13 \%$ compared to baseline in the $45^{\circ}$ semi-Fowler position. In the high-risk group, the blood flow decreased $28 \%$ and $14 \%$ in the respective positions. However, their study did not report tests of significance between positions or groups. Another study among an elderly in-patient population reported increased blood flow over the sacrum in the $0^{\circ}$ supine position while lying on a standard hospital mattress for 10 minutes (Bergstrand et al., 2014). In a study by Ek et al. (1987), it was shown that blood flow was more affected over the heels than over the sacrum in a $0^{\circ}$ supine position. The heel blood flow decreased significantly, while the blood flow over the sacrum remained unchanged. The study was conducted with a sample of 21 elderly hemiplegic patients who rested on a standard mattress in a supine position for 5 minutes.

Frantz et al. (1993) used laser-Doppler technique to measure blood flow over the trochanter major in a $90^{\circ}$ lateral position over the course of one hour in an elderly patient population. In the study, all included patients were considered to be at high risk for pressure ulcer development. Although the blood flow remained unchanged at the group level after one hour, they observed that 4 of the 16 patients had an increased blood flow during load, 8 of the 16 had a decreased blood flow, and for the remaining 4 patients the blood flow was unchanged. They concluded that considerably more variability in blood flow exists in at-risk patients than had previously been believed. 
Although the measurements in the studies mentioned above have been made in different positions, the evaluation and comparison of these findings is difficult to do because of the different study designs. Furthermore, the blood flow responses were only measured in the most superficial skin. Because the weight-bearing tissue is not uniformly affected by the mechanical load (Oomens et. al, 2010), it is interesting to evaluate blood flow responses at different tissue layers simultaneously.

\section{Rationale}

To reduce risk for pressure ulcers, repositioning of immobile patients is an important standard nursing practice. However, knowledge on how this preventive intervention is carried out among elderly immobile patients is limited. Furthermore, to what extent patients perform minor movements between nursing staff-induced repositionings is largely unknown, but these movements might have implications for the preventive interventions. Different lying positions are used in repositioning schedules, but there is lack of evidence to recommend specific positions. Because pressure ulcers might result from ischemia, it is useful to study how the tissue blood flow on different levels is affected by pressure. Measurements of tissue blood flow together with skin temperature and interface pressure might be suitable for comparison of different lying positions. Because the skin becomes more vulnerable to pressure and shear with advanced age, and because pressure ulcers are most common among the elderly, it is important to perform these studies in an elderly patient population.

The studies in this thesis are based on a theoretical framework where the concepts of immobility, pressure, repositioning and ischemia are essential (Figure 2). 
항

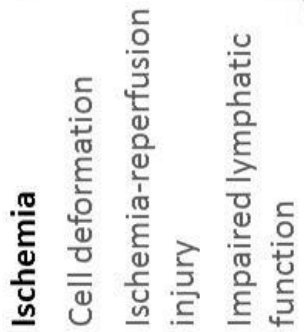

$\frac{\sqrt{5}}{3}$

:

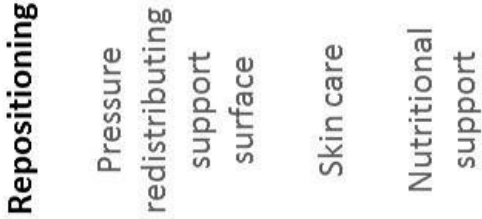

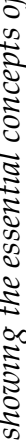

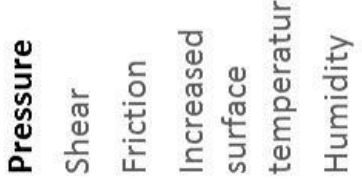

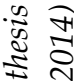

.

పे

高

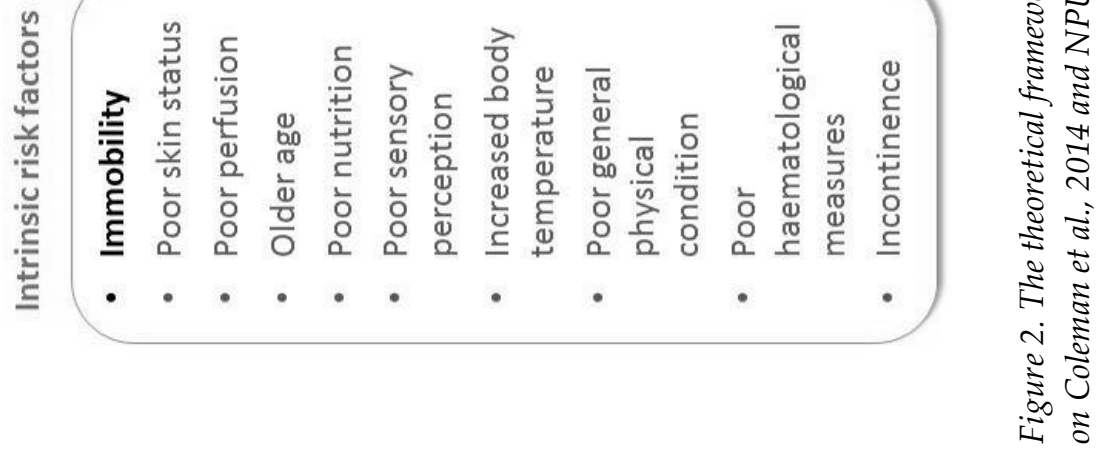





\section{AIMS}

The overall aim of this thesis was to describe and evaluate how repositioning procedures work in practice in the care of elderly immobile patients. The aim was also to compare the effects of different positions with regard to interface pressure, skin temperature, and tissue blood flow in elderly patients lying on a pressure-redistribution mattress.

Specific aims of the studies:

- To investigate nursing staff-induced repositionings and the patients' spontaneous movements during the day and night among older immobile patients in nursing care. Furthermore, the aim was to identify factors associated with the nursing staff-induced repositionings and the patients' spontaneous movement frequency (Study I).

- To pilot and evaluate the design and procedures for a study to compare the effects of different lying positions on tissue blood flow and skin temperature in older adult patients (Study II).

- To compare the effects of different lying positions on interface pressure, skin temperature, and tissue blood flow at three tissue depths during 1hour measurements in nursing home residents (Study III).

- To describe individual PIV responses in a nursing home resident population for 1-hour periods of bed rest (Study IV). 



\section{METHODS}

\section{Design and settings}

This thesis is based on an atomistic-empiric epistemology, where the researcher has the goal of finding empirical evidence and universal roles (Polit \& Beck, 2010). Within this paradigm, the researcher seeks to objectively describe the variables being studied and their relationships to each other by evaluating the results, consequences, or effects of a completed action (Figure 2). Thus, quantitative methods were chosen for the four studies where Study I has an observational cross-sectional study design with between-subject comparisons, Study II and III have an experimental descriptive comparative design with within-subject comparisons, and Study IV has an experimental descriptive design with between-subject comparisons. An overview of the study designs and participants is presented in Table 1.

In total, 107 patients from hospital care (Studies I and II) and nursing homes (Studies I, III, and IV) participated in the studies. The research was undertaken in both a controlled laboratory setting (Study II) and in the field (Studies I, III, and IV).

In Study I, a convenience sample from eight nursing homes (29 participants) and seven hospital departments (33 participants) was recruited. The hospital wards included pulmonary medicine, internal medicine, rehabilitation, haematology, oncology, geriatric orthopaedics, surgery, and palliative care.

Study II served to pilot and evaluate the design and procedures for Study III. A convenience sample of 20 elderly adult in-patients was recruited from the neurological, medical emergency, and geriatric wards at a university hospital. The measurements of blood flow and temperature in six different lying positions were made in a laboratory at the hospital, and all measurements took place on the same occasion for each participant.

In Study III, a new convenience sample was recruited $(n=25)$ from three nursing homes located in southern Sweden, and the measurements were made in the participants' own rooms. The sample size was based on Study II and was calculated to observe a $50 \%$ difference in mean blood flow between baseline and at $60 \mathrm{~min}$ with a power of $80 \%$. For Study III, the measurement time in each position was extended from 5 minutes to 1 hour to better replicate a typical clinical situation. The number of positions evaluated was reduced from six to 
four (the semi-Fowler positions were excluded, Figure 5), and the measurements in each position were performed on different days so that the procedure would not be too strenuous for the participants. Study IV was based on the same sample as Study III.

Table 1. Overview of the study designs and participants in Studies I-IV.

\begin{tabular}{|c|c|c|c|c|c|}
\hline & Study design & Sample size & $\begin{array}{l}\text { Data } \\
\text { collection } \\
\text { (years) }\end{array}$ & $\begin{array}{l}\text { Inclusion } \\
\text { criteria }\end{array}$ & $\begin{array}{l}\text { Exclusion } \\
\text { criteria }\end{array}$ \\
\hline Study I & $\begin{array}{l}\text { Observational } \\
\text { cross-sectional, } \\
\text { between- } \\
\text { subjects } \\
\text { comparison }\end{array}$ & $\begin{array}{l}29 \text { patients } \\
\text { from nursing } \\
\text { homes and } 33 \\
\text { from hospital } \\
\text { care }\end{array}$ & $\begin{array}{l}2012- \\
2014\end{array}$ & $\begin{array}{l}\geq 65 \text { years of } \\
\text { age and } \leq 2 \mathrm{p} \\
\text { in the } \\
\text { variables } \\
\text { Mobility and } \\
\text { Physical } \\
\text { Activity } \\
\text { according to } \\
\text { the RAPS }\end{array}$ & $\begin{array}{l}\text { Skin sensitivity } \\
\text { towards the } \\
\text { adhesive } \\
\text { dressing being } \\
\text { used or not } \\
\text { being able to } \\
\text { complete the } \\
\text { observational } \\
\text { period }\end{array}$ \\
\hline Study II & $\begin{array}{l}\text { Experimental } \\
\text { descriptive, } \\
\text { within-subject } \\
\text { comparison. } \\
\text { Pilot study }\end{array}$ & $\begin{array}{l}20 \text { patients } \\
\text { from hospital } \\
\text { care }\end{array}$ & 2010 & $\begin{array}{l}\geq 65 \text { years of } \\
\text { age and } \\
\text { ability to lie } \\
\text { in all } \\
\text { positions }\end{array}$ & $\begin{array}{l}\text { Patients with } \\
\text { body } \\
\text { temperature } \\
>37.5^{\circ} \mathrm{C} \text {, or skin } \\
\text { damage in the } \\
\text { sacrum, gluteus } \\
\text { maximus, or } \\
\text { trochanter areas. }\end{array}$ \\
\hline Study III & $\begin{array}{l}\text { Experimental } \\
\text { descriptive, } \\
\text { within-subject } \\
\text { comparison }\end{array}$ & $\begin{array}{l}25 \text { patients } \\
\text { from nursing } \\
\text { homes }\end{array}$ & $\begin{array}{l}2011- \\
2012\end{array}$ & $\begin{array}{l}\geq 65 \text { years of } \\
\text { age and } \\
\text { ability to lie } \\
\text { in all } \\
\text { positions }\end{array}$ & $\begin{array}{l}\text { Patients with } \\
\text { body } \\
\text { temperature } \\
>37.5^{\circ} \mathrm{C} \text {, or skin } \\
\text { damage in the } \\
\text { sacrum or } \\
\text { trochanter areas. }\end{array}$ \\
\hline Study IV & $\begin{array}{l}\text { Experimental } \\
\text { descriptive, } \\
\text { between- } \\
\text { subject } \\
\text { comparison }\end{array}$ & $\begin{array}{l}25 \text { patients } \\
\text { from nursing } \\
\text { homes }\end{array}$ & $\begin{array}{l}2011- \\
2012\end{array}$ & $\begin{array}{l}\geq 65 \text { years of } \\
\text { age and } \\
\text { ability to lie } \\
\text { in all } \\
\text { positions }\end{array}$ & $\begin{array}{l}\text { Patients with } \\
\text { body } \\
\text { temperature } \\
>37.5^{\circ} \mathrm{C} \text { or skin } \\
\text { damage in the } \\
\text { sacrum or } \\
\text { trochanter areas. }\end{array}$ \\
\hline
\end{tabular}

RAPS $=$ Risk Assessment Pressure Ulcer Scale 


\section{Participants}

Elderly people living in nursing homes are usually referred to as residents, but to facilitate readability in this thesis all participants are referred to as patients. In order to capture the elderly patient population, an age of 65 years or older was an inclusion criterion in all studies. The remaining inclusion and exclusion criteria are presented in Table 1 . The nursing staff of the nursing homes and the hospitals was contacted for possible participating patients. Each patient received information about the study both orally and in writing. If the patient was not able to give informed consent, next of kin received this information. After written informed consent, either from the patient or the next of kin, the patients were included in the studies.

\section{Data collection}

An overview of measurements, variables, and procedures used in Studies I-IV is presented in Table 2 .

\section{Clinical data}

Clinical data such as age, medical history, and current medications were obtained from the patients' records and noted in the study protocols. Weight and height were measured in the laboratory in Study II, but in Studies I, III, and IV these data were collected from the patients' records. All patients were risk assessed for pressure ulcer development using the Risk Assessment Pressure Ulcer Scale (RAPS, (Lindgren et al., 2002) by the researcher together with the nursing staff. The RAPS consists of nine variables, including general physical condition, physical activity, mobility, moisture, food intake, fluid intake, sensory perception, friction and shear, and body temperature. The maximum score is 35 , and patients with scores less than or equal to 29 are considered to be at risk for pressure ulcer development. The reliability and validity of RAPS has been tested with good interclass correlation (0.83) and good balance between sensitivity (78\%) and specificity (70\%) within a general hospital setting (Källman \& Lindgren, 2014; Lindgren et al., 2002). 
Table 2. Overview of measurements, variables, and procedures used in Studies I-IV.

\section{Procedure}

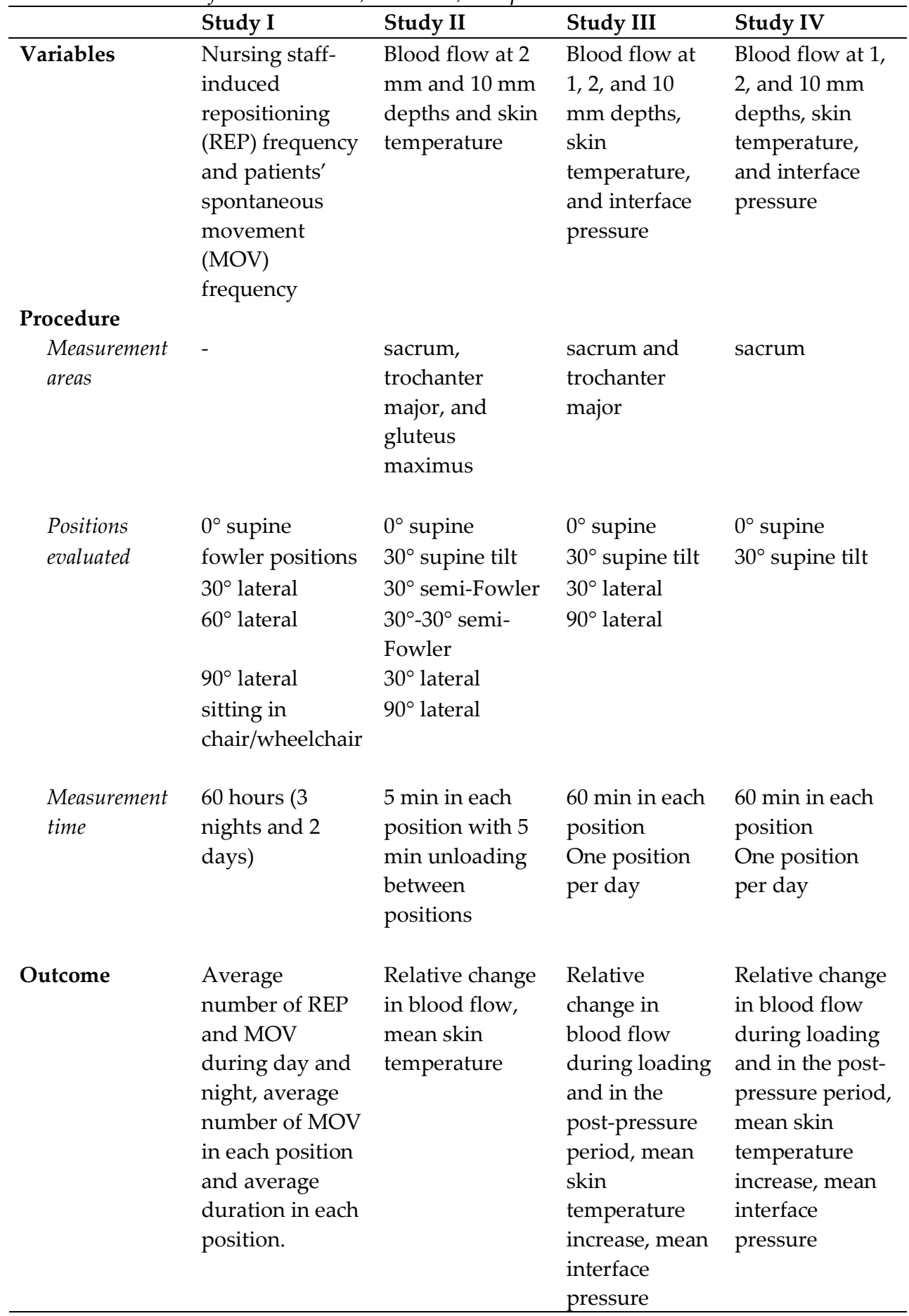


Study I used a protocol based on the Swedish version of the EPUAP minimal data set (Gunningberg et al., 2006) to collect further information about pressure ulcer category 1-4 and location if present, prevention measures such as pressure-redistribution mattresses, planned interval for repositioning, and preventive aids (e.g. positioning pillows, slide sheet, heel support).

\section{Measurements}

\section{Patients spontaneous movements}

In Study I, the patients' movements were measured with the MovinSense (MiS) care management system (Kinematix, Porto, Portugal). The MiS is a wireless microelectronic device developed to automatically monitor and document the patient's movements. The system consists of software, a transmitter, and a receiver. The transmitter (Figure 3) is a small and light-weight instrument 4.2 $\mathrm{cm}$ in diameter that is fixed onto the patient's chest with adhesive tape. Before the transmitter is fixed, the patient is registered into the software and the transmitter is configured. For this study, the device was configured to register movements of more than $25^{\circ}$ in any direction and with duration of more than 5 seconds. During the measurements, the transmitter registers when (date and time) and how (position and angle) the patient makes a position change, either with help from the staff or spontaneously. When the measurement period is completed, the data are downloaded via a receiver to the software program in a computer. The MiS device has a warning system that is used to alert the nursing staff if the patient has not moved on his/her own within a predetermined amount of time. This warning function was deactivated in this study, and the nursing staff had no access to the MiS data.

The MiS device was validated in Study I. The registrations by MiS were compared with 363 staff notes regarding position and estimated angle, and the congruence was $92.3 \%$.

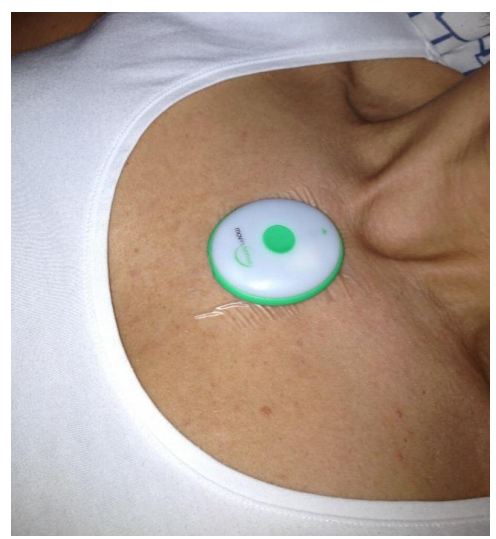

Figure 3. The MovinSense transmitter fix to the chest with adhesive dressing 


\section{Blood flow, interface pressure, and skin temperature}

In Studies II-IV, blood flow in the tissue was measured at different depths simultaneously and noninvasively using two optical instruments, photoplethysmography (PPG) and laser Doppler flowmetry (LDF). These two components were combined into a single probe that was developed in-house (Figure 4).

PPG has widespread clinical applications and is available in many medical devices, such as pulse oximeters, vascular diagnostics, and digital beat-to-beat blood pressure measurements systems, and can provide valuable information about the cardiovascular system (Allen, 2007). The PPG technology consists of a light source to illuminate the skin and a photodetector to measure the variations in light intensity associated with changes in blood flow in the underlying tissue. The depth to which the light penetrates is determined by the wavelength and distance between the light-emitting diode (LED) and the photodetector (Lindberg \& Öberg, 1993; Zhang, 2001). The reflected light generates a two-component signal of which one, the AC signal, has a pulsatile waveform in sync with the heart rate and reflects the arterial blood flow. The other signal, called the DC signal, relates to the average blood volume and varies slowly due to respiration, vasomotor activity, and vasoconstrictor waves (Allen, 2007; Lindberg \& Öberg, 1993). Because this thesis focused on blood flow, only the AC signal was analysed.

The two-channel PPG instrument and the PPG probe used in Studies I-III was developed at the Department of Biomedical Engineering (Figure 4) (Linköping University, Linköping, Sweden). The probe consists of six green LEDs $(560 \mathrm{~nm})$ at a distance of $3.4 \mathrm{~mm}$ from the photo detectors and four near infrared (IR) LEDs $(810 \mathrm{~nm}$ ) at a distance of $25 \mathrm{~mm}$ from the photodetectors. These wavelengths monitor the blood flow at a depth of approximate $2 \mathrm{~mm}$ and $10 \mathrm{~mm}$, respectively (Hagblad et al., 2010). The diodes and detectors are embedded in a thin, flexible, black silicon plate measuring $10 \mathrm{~mm} \times 10 \mathrm{~mm}$. In Study II, two identical probes were used, and in Studies III and IV only one probe was used.

To measure the most superficial blood flow at approximately $1 \mathrm{~mm}$ depth (Fredriksson et al., 2009), LDF (Periflux, PeriMed, Järfälla, Sweden) and the fiber-optic probe (PeriMed 415-242 SPP, PeriMed, Järfälla, Sweden) were added in Studies III and IV. LDF is a well-established method and has been used in various research projects for evaluating the microvascular blood flow in tissue (Ek et al., 1987; Humeau et al., 2007). For example, clinical 


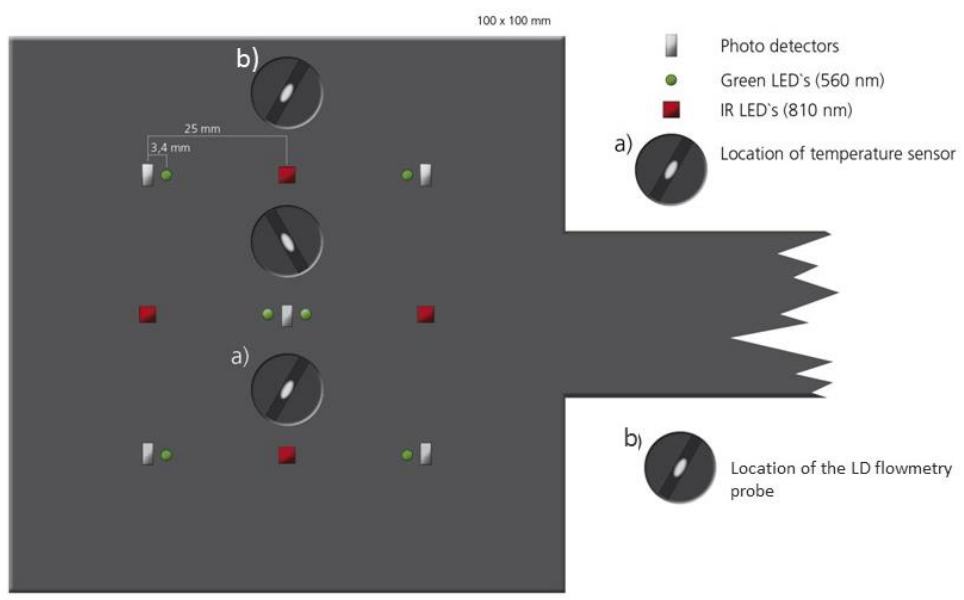

Figure 4. The optical probe with green and near infrared (IR) light-emitting diodes (LEDs) and photodetectors used in Studies II-IV. LD = laser Doppler.

applications of the technique are related to diabetes microangiopathy, peripheral vascular diseases, pharmacological applications, and skin diseases (Hodges et al., 2014; Rossi et al., 2004; Stansberry et al., 1997). LDF uses monochromatic light with a wavelength of $780 \mathrm{~nm}$. One fiber in the optical laser Doppler probe leads the light to the tissue, and a second optical fiber collects the backscattered light and transmits it to a photodetector. In the tissue, photons are scattered by moving objects; e.g. red blood cells and by static structures. Encounter with moving cells causes frequency shifts, and the LDF detects these shift as an estimate of the blood flow in arbitrary units.

Skin temperature was measured with a single sensor (PF422, PeriMed, Järfälla, Sweden) integrated in the optical probes (Figure 4).

In Study III - IV, measurements of interface pressure were added. Measurements were made with a thin flexible pneumatic pressure transmitter connected to a digital manometer that was developed in-house. 


\section{Other measurements}

In the protocol for Study I, the nursing staff documented each occasion that they helped the patient reposition themselves. Time, position, position angle, and daily activity, if any, in connection with the repositioning were collected.

In Studies II-IV, the following patient data were also collected: blood pressure (mmHg, manually measured with a calibrated blood pressure cuff, Speidel \& Keller, Jungingen, Germany), heart rate (manually monitored for a one-minute period), and body temperature (Measured in ${ }^{\circ} \mathrm{C}$, Skin Spot Sensor 442-PI, PeriMed, Järfälla, Sweden, in Study II; ThermoScan 6022, Braun, Kronoberg, Germany, in Studies III and IV).

During the procedures, the room temperature was measured in ${ }^{\circ} \mathrm{C}$ using a digital thermometer (type 565; Schwille Electronic, Kircheim, Germany, in Study II; Bell Xpress A/S; Tranbjerg, Denmark, in Studies III and IV).

\section{Procedure}

\section{Study I}

The procedure to collect data in Study I was planned for a 60-hour period (three nights and two days). The measurement with MiS and the nursing staff documentations started on the afternoon of day one and ended in the morning of day four. The installation of MiS, i.e. the MiS transmitter configuration, fixation to the patients' chest, and start of the device, was performed by the author.

\section{Studies II-IV}

The same pressure-redistribution mattress constructed of $14 \mathrm{~cm}$ thick cold foam consisting of two layers with densities of $65 \mathrm{~kg} / \mathrm{m}^{3}$ and $50 \mathrm{~kg} / \mathrm{m}^{3}$ (Optimal $5 \mathrm{zon}$; Care of Sweden, Tranemo, Sweden) was used for all the patients. The mattress was placed on the mesh base and was covered with a single cotton sheet. 
The positions evaluated in the studies are presented in Table 2 and Figure 5 . The $30^{\circ}$ supine tilt position was created by using two triangle-shaped wedges placed side by side under the mattress. The wedges were also used to create the $30^{\circ}-30^{\circ}$ semi-Fowler position with bent knees. In the lateral positions, the patients lay with bent hip and knees and their back was supported with a regular pillow (Study II) or positioning pillow (Curea Multi pillow, Care of Sweden, Tranemo, Sweden) (Study III).

In supine positions, the blood flow (Studies II-IV), skin temperature (Studies II-IV), and interface pressure (Studies III and IV) were measured over the sacrum, and in lateral positions they were measured over the trochanter major. In Study II, the measurements were also performed over the gluteus maximus muscle area. The bony prominences of the sacrum and trochanter major were identified by palpation, and the middle of the gluteus maximus was outlined by identifying the four quadrates of the muscle. The probes were centred over the identified areas and fixed to the skin with gentle adhesive tape.
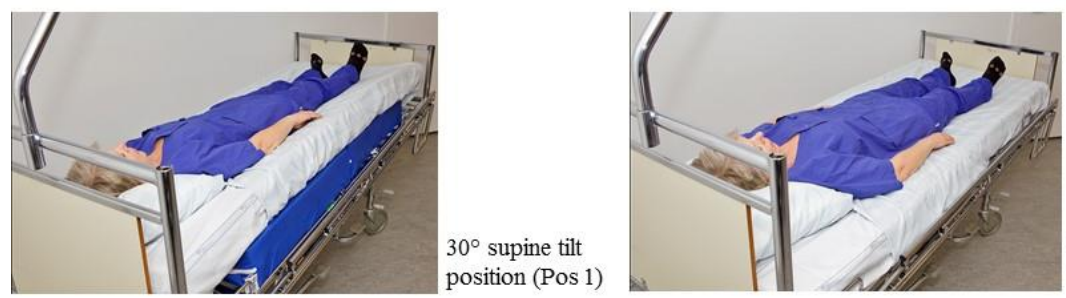

$0^{\circ}$ supine position (Pos 2)
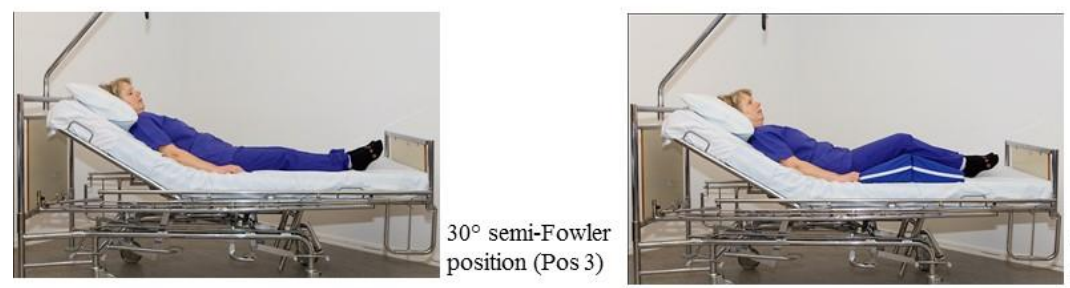

$30-30^{\circ}$ semi-Fowler position (Pos 4)
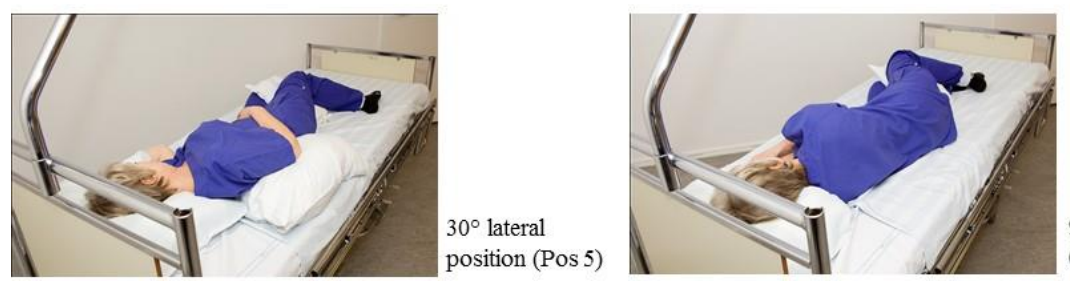

$90^{\circ}$ lateral position (Pos 6)

Figure 5. Positions (Pos) evaluated in Study II (Pos 1-6), Study III (Pos 1, 2, 5, and 6), and Study IV (Pos 1 and 2). 
In Study II, the probes were placed while the patient stood up, and in Studies III and IV the probes were placed during the first minutes while lying in the bed. The patients rested for 15 minutes in a lateral position to acclimatize to the bed rest (Bergstrand et al., 2014; Daly \& Henry, 1980). At the end of this period, the patient's body temperature, pulse, and systolic and diastolic blood pressure were measured, the room temperature was noted, and the first baseline data of blood flow, skin temperature, and interface pressure were collected (Figure 6 and Figure 7).

The procedure in Study II was as follows (Figure 6). The patient was carefully positioned into the $30^{\circ}$ supine tilt position, and measurements of blood flow and skin temperature continued over the sacrum and gluteus maximus. This was followed by the $0^{\circ}$ supine position, the $30^{\circ}$ semi-Fowler position, and the $30^{\circ}-30^{\circ}$ semi-Fowler position. After these measurements, the probe over the sacrum was moved to the trochanteric area and measurements continued in the $30^{\circ}$ lateral position and finally in the $90^{\circ}$ lateral position. The patients lay in each position for 5 minutes and unloaded the measurement areas by resting on his/her side for 5 minutes between each position. At the end of each unloaded period, new baseline data were collected.

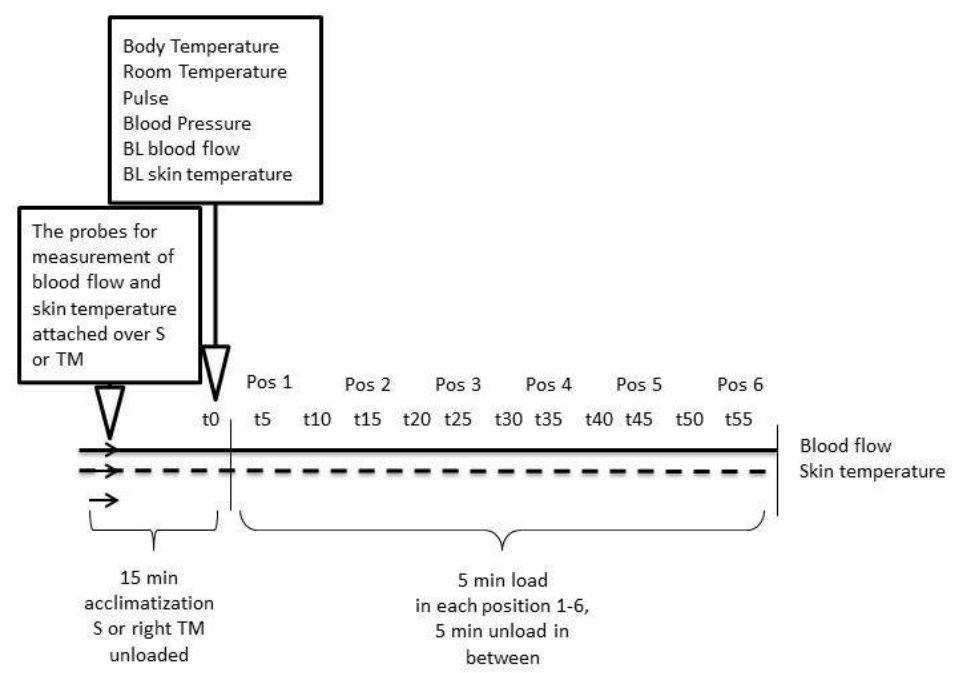

Figure 6. Schematic description of the measurement procedure in Study II. Blood flow and skin temperature were continuously recorded from the moment after the probes were affixed. At $t 0, t 10, t 20, t 30, t 40$, and $t 50$, baseline data were collected and compared to the next related position. Note. $B L=$ baseline; $S=$ sacrum; $T M=$ trochanter major; Pos $1=30^{\circ}$ supine tilt; Pos $2=0^{\circ}$ supine; Pos $3=30^{\circ}$ semi-Fowler; Pos $4=30^{\circ}-30^{\circ}$ semi-Fowler; Pos $5=30^{\circ}$ lateral; Pos $6=90^{\circ}$ lateral. 
The procedure in Study III was as follows after the acclimatization period (Figure 7): The patient was positioned to either a $30^{\circ}$ supine tilt position, $0^{\circ}$ supine position, $30^{\circ}$ lateral position, or $90^{\circ}$ lateral position, and blood flow, skin temperature, and interface pressure were measured continuously over the course of 60 minutes. The patient was repositioned to a lateral position in order to unload the measurement area, and the measurements of blood flow and skin temperature were recorded for an additional ten minutes. The positions were evaluated one at a time in each patient on four different occasions within a median of 7 ( $\mathrm{q} 1=6, \mathrm{q} 3=9)$ days. The measurements were performed at the same time of the day on each occasion. The procedure in Study IV was the same as in Study III except that the lateral positions were excluded.

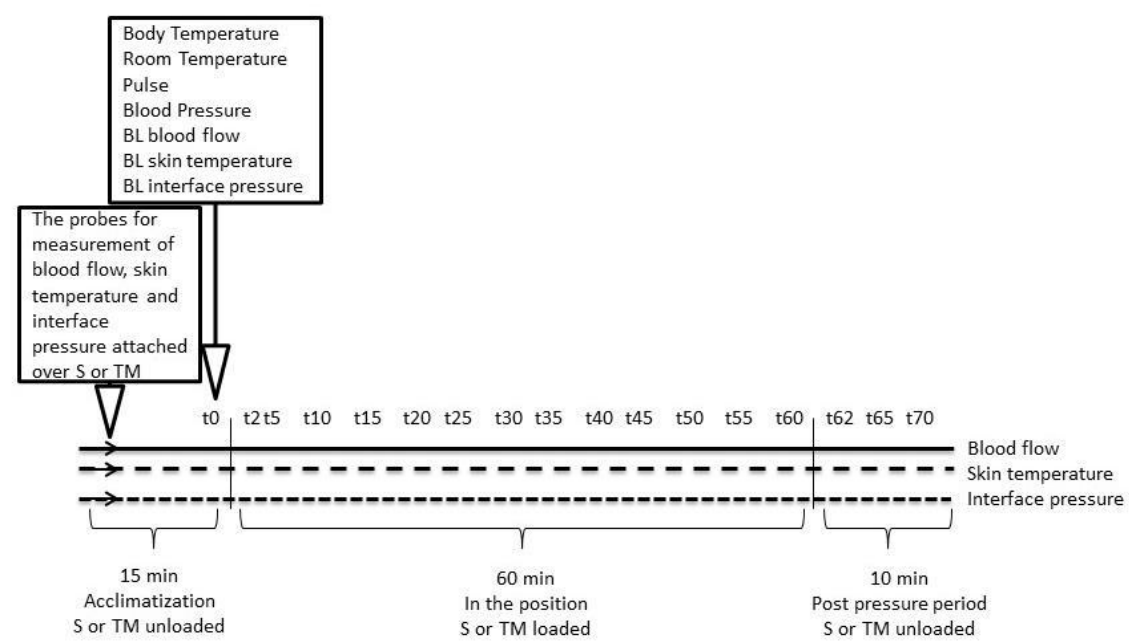

Figure 7. Schematic description of the measurement procedure in Studies III and IV. Blood flow, skin temperature, and interface pressure were continuously recorded from the moment after the probe was affixed. The measurements over the TM were not included in Study III. Note. $B L=$ baseline; $S=$ sacrum; $T M=$ trochanter major.

\section{Data analysis}

In all studies, the patient's body mass index (BMI) was calculated as weight in kilograms / (height in meters) ${ }^{2}$. The range of normal BMI should be adjusted upwards in the elderly, and an interval of 23-29 for normal BMI has been suggested (Cederholm, 2011) and was used in this thesis. In Study II, the mean arterial pressure (MAP) was calculated as a function of diastolic pressure (DP) and systolic pressure (SP): MAP $=\mathrm{DP}+(\mathrm{SP}-\mathrm{DP}) / 3$. 


\section{Study I}

Movements registered by MiS were compared with the nursing staff notes, and movements were coded as either spontaneous or induced by the staff. A movement was defined as staff induced if the movement registered by MiS was from supine to sitting up, from left to right, etc. and if the movement was in congruence with the nursing staff notes in terms of time, position, and daily activity in connection to the position change. All other movements were coded as spontaneous. Movements from an entire day or night were excluded from the analysis if $10 \%$ or more could not be defined as either spontaneous or nursing staff induced.

The number of nursing staff-induced repositionings (REP) and patients' spontaneous movements (MOV) was divided into 12-hour episodes corresponding to daytime and nighttime. The daytime interval was between the hours of 8 a.m. -8 p.m. and was chosen to include breakfast and evening meals and the standard routine to preparing for night rest before the end of the staff evening shift that finished at 9 p.m. Any data collected before 8 p.m. on day one and after 8 a.m. on day four were not included in the analyses. If MiS data or nursing staff notes not were complete for at least one 12-hour period, the participant was excluded from the analysis. This resulted in a dropout of 10 patients and thus the analysis was based on 52 patients with a range of one to five 12-hour episodes. The following calculations were made for each patient: the average number of REP during the day and night was calculated as the total REP divided by the total number of complete days and nights, the average number of MOV during the day and night was calculated as the total MOV divided by the total number of complete days and nights, the average duration in each position was calculated as the total time in each position divided by the total number of occasions in each position, and the average number of MOV in each position was calculated as the total MOV in each position divided by the total number of occasions in each position.

The positions were divided into categories according to staff notes and defined as follows:

- $0^{\circ}-19^{\circ}$ supine position $=0^{\circ}$ supine position,

- supine position with head of the bed elevated $>20^{\circ}=$ semi-Fowler positions,

- $20^{\circ}-40^{\circ}$ lateral position $=30^{\circ}$ lateral position,

- $41^{\circ}-70^{\circ}$ lateral position $=60^{\circ}$ lateral position,

- $\quad>71^{\circ}$ lateral position $=90^{\circ}$ lateral position, and

- sitting in a chair/wheelchair. 


\section{Studies II-IV}

The signals from blood flow (Studies II-IV), skin temperature (Studies II-IV), and interface pressure (Studies III and IV) were simultaneously recorded on a laptop PC at a sampling frequency of $75 \mathrm{~Hz}$ (Labview 6.1; National Instruments, Kista, Sweden). The signals were analysed using a program developed in-house (Department of Biological Engineering, Linköping University, Linköping, Sweden).

In Study II, a 30-second signal period was analysed at the end of the unloading periods, which gave six baseline values (Figure 6). Likewise, a 30second signal period was analysed at the end of each position. Each position value was then calculated as the relative change in percentage from its related baseline values. This was done to adjust for the temperature increase during the measurement procedure.

In Studies III and IV, a 30-second signal period was analysed just before loading (baseline) and thereafter at 5-minute intervals during the 60-minute loaded and 10-minute unloaded periods in each position (Figure 7). A 30-second period of interface pressure signal was analysed at baseline and after 2 minutes of loading and converted from volts to millimetres of mercury by linear equation (Poole, 2003).

The blood flow in each measurement was calculated as the relative change from baseline as a percentage.

In Study IV, the blood flow during loading was calculated as the mean relative change in percentage of the twelve measurement points (t5 to 160 in Figure 7), and based upon the LDF data the patients were divided into the PIV group (mean blood flow above baseline) and the non-PIV group (mean blood flow below baseline). The participants who did not have the same PIV response in both positions $(n=2)$, those who lacked LDF data in either position $(n=2)$, and those who could not complete the measurement period of one hour in at least one of the positions $(n=3)$ were excluded from the analysis. This resulted in a dropout of 7 patients, and thus the analysis was based on 18 patients in this study.

In the post-pressure period (t62 to t70), the peak blood flow was identified (Study III). 


\section{Statistics}

An overview of the statistics used in the studies is presented in Table 3. Categorical data are presented as numbers and percentages, and continues data are presented as means and standard deviations (SD) and/or as medians and interquartile ranges (IQR). In Study III, imputation was made for missing data regarding pulse and systolic and diastolic blood pressure and was calculated as the mean of the values measured during the other sessions (Piantadosi, 2005).

Spearman's correlation coefficient was used to express relationship between REP and/or MOV frequency with type of health care, gender, BMI, total RAPS, relevant RAPS variables, pressure ulcer, pressure ulcer preventive interventions, relevant diagnoses, and medications. Multiple regression analysis was performed in Study I to find factors independently related to either REP or MOV frequency. Variables that were significantly correlated to REP or MOV in a Spearman's rho correlation test were used as independent variables. The dependent variable MOV during the night was logarithmically transformed ( $\left.\log _{10}\right)$ before analysis due to non-normal distribution (Altman, 1999).

In Study I, a two-way ANOVA was performed to examine if there was any difference in MOV frequency between the positions and between the patients. Positions was used as the fixed factor and patients as the random factor.

In Study II, an analysis of covariance (ANCOVA) was used to compare blood flow responses between positions and patients (model 1) adjusted for the skin temperature. In this analysis, blood flow at $2 \mathrm{~mm}$ or $10 \mathrm{~mm}$ depth was the dependent variable, positions was a fixed factor, patients was a random factor, and skin temperature was the covariate. To see if the variation between the patients could be divided into components, a further ANCOVA was carried out (model 2). Instead of patients as the random factor, gender, age, mean arterial pressure, BMI, total RAPS-score, body temperature, and skin temperature were added as covariates (Kutner et al., 2004).

A repeated measures ANOVA was carried out in Study III to compare means of the patients' systolic and diastolic blood pressure and body temperature between the measurement sessions. A further repeated measures ANOVA was carried out to compare the means of interface pressure, skin temperature at baseline, and skin temperature after $60 \mathrm{~min}$ of loading. The homogeneity of variance and the normal distribution of residuals were checked in all ANOVA and ANCOVAs (Pallant, 2010). 
Table 3. Study-specific statistical tests.

\begin{tabular}{|c|c|c|c|c|c|}
\hline \multirow[b]{2}{*}{ Method } & \multirow[b]{2}{*}{ Data } & \multicolumn{3}{|c|}{ Application } & \multirow[b]{2}{*}{ Study IV } \\
\hline & & Study I & Study II & Study III & \\
\hline $\begin{array}{l}\text { ANCOVA } \\
\text { post hoc test } \\
\text { with Sidak } \\
\text { correction } \\
\text { (no post hoc } \\
\text { test in Model } \\
\text { 2) }\end{array}$ & $\begin{array}{l}\text { Continuous, } \\
\text { more than } \\
\text { two } \\
\text { independent } \\
\text { variables }\end{array}$ & & $\begin{array}{l}\text { BF at } 2 \mathrm{~mm} \\
\text { and } 10 \mathrm{~mm} \\
\text { depth with } \\
\text { regard to } \\
\text { positions, } \\
\text { individuals, } \\
\text { and skin } \\
\text { temperature } \\
\text { (Model 1) or } \\
\text { positions and } \\
\text { covariates } \\
\text { (Model 2) }\end{array}$ & & \\
\hline $\begin{array}{l}\text { Fisher's } \\
\text { exact test }\end{array}$ & $\begin{array}{l}\text { Categorical, } \\
\text { two } \\
\text { independent } \\
\text { groups }\end{array}$ & & & & $\begin{array}{l}\text { Genders in } \\
\text { the PIV and } \\
\text { non-PIV } \\
\text { groups }\end{array}$ \\
\hline $\begin{array}{l}\text { Longitudinal } \\
\text { linear } \\
\text { mixed- } \\
\text { model } \\
\text { analysis }\end{array}$ & $\begin{array}{l}\text { Continuous, } \\
\text { more than } \\
\text { two } \\
\text { independent } \\
\text { variables }\end{array}$ & & & $\begin{array}{l}\text { Compare BF } \\
\text { between } \\
\text { positions and } \\
\text { tissue depths } \\
\text { adjusted for } \\
\text { confounding } \\
\text { variables }\end{array}$ & \\
\hline $\begin{array}{l}\text { Mann- } \\
\text { Whitney U- } \\
\text { test }\end{array}$ & $\begin{array}{l}\text { Continuous, } \\
\text { two } \\
\text { independent } \\
\text { groups }\end{array}$ & & $\begin{array}{l}\text { BF between } \\
\text { risk vs. non- } \\
\text { risk patients } \\
\text { for PU }\end{array}$ & & $\begin{array}{l}\text { Mean BF } \\
\text { during load } \\
\text { and peak } \\
\text { BF in PPP } \\
\text { between the } \\
\text { PIV and } \\
\text { non-PIV } \\
\text { group }\end{array}$ \\
\hline $\begin{array}{l}\text { Multiple } \\
\text { regression } \\
\text { analysis } \\
\text { with } \\
\text { backward } \\
\text { method }\end{array}$ & $\begin{array}{l}\text { Continuous, } \\
\text { more than } \\
\text { two } \\
\text { variables }\end{array}$ & $\begin{array}{l}\text { Analysis of } \\
\text { REP or } \\
\text { MOV } \\
\text { frequency } \\
\text { with } \\
\text { significant } \\
\text { correlated } \\
\text { variables }\end{array}$ & & & \\
\hline
\end{tabular}


Table 3. Continued

\begin{tabular}{|c|c|c|c|c|c|}
\hline \multirow[b]{2}{*}{ Method } & \multirow[b]{2}{*}{ Data } & \multicolumn{3}{|c|}{ Application } & \multirow[b]{2}{*}{ Study IV } \\
\hline & & Study I & Study II & Study III & \\
\hline $\begin{array}{l}\text { Repeated } \\
\text { measures } \\
\text { ANOVA } \\
\text { with } \\
\text { Bonferroni } \\
\text { test for post } \\
\text { hoc } \\
\text { comparison }\end{array}$ & & & $\begin{array}{l}\text { Differences } \\
\text { between } \\
\text { positions } \\
\text { with regards } \\
\text { to skin } \\
\text { temperature }\end{array}$ & $\begin{array}{l}\text { Differences } \\
\text { between } \\
\text { occasions with } \\
\text { regards to SP, } \\
\text { DP, Interface } \\
\text { pressure, room } \\
\text { temperature, } \\
\text { skin- and body } \\
\text { temperature }\end{array}$ & \\
\hline $\begin{array}{l}\text { Spearman's } \\
\text { correlation } \\
\text { coefficient }\end{array}$ & $\begin{array}{l}\text { Continuous, } \\
\text { two } \\
\text { variables }\end{array}$ & $\begin{array}{l}\text { Relationship } \\
\text { between REP } \\
\text { and/or MOV } \\
\text { frequency } \\
\text { with relevant } \\
\text { background } \\
\text { data }\end{array}$ & & & \\
\hline $\begin{array}{l}\text { Student's } t \text { - } \\
\text { test }\end{array}$ & $\begin{array}{l}\text { Continuous, } \\
\text { two } \\
\text { independent } \\
\text { groups }\end{array}$ & & & $\begin{array}{l}\text { Background } \\
\text { data between } \\
\text { genders and } \\
\text { risk vs. non- } \\
\text { risk patients } \\
\text { for pressure } \\
\text { ulcer } \\
\text { development }\end{array}$ & $\begin{array}{l}\text { Background } \\
\text { data } \\
\text { between } \\
\text { PIV and } \\
\text { non-PIV } \\
\text { group }\end{array}$ \\
\hline $\begin{array}{l}\text { Two-way } \\
\text { ANOVA } \\
\text { with } \\
\text { Tukey's test } \\
\text { for post hoc } \\
\text { comparison }\end{array}$ & $\begin{array}{l}\text { Continuous, } \\
\text { more than } \\
\text { two } \\
\text { independent } \\
\text { variables }\end{array}$ & $\begin{array}{l}\text { MOV } \\
\text { frequency } \\
\text { with regard to } \\
\text { positions and } \\
\text { individuals }\end{array}$ & & & \\
\hline $\begin{array}{l}\text { Wilcoxon } \\
\text { matched } \\
\text { pairs } \\
\text { signed-rank } \\
\text { sum test }\end{array}$ & $\begin{array}{l}\text { Continuous, } \\
\text { two } \\
\text { dependent } \\
\text { groups }\end{array}$ & $\begin{array}{l}\text { REP and } \\
\text { MOV } \\
\text { frequency } \\
\text { between } \\
\text { nights and } \\
\text { days }\end{array}$ & $\begin{array}{l}\text { BF response } \\
\text { compared } \\
\text { between } \\
\text { baseline and } \\
\text { after } 5 \mathrm{~min}\end{array}$ & $\begin{array}{l}\text { BF response } \\
\text { compared } \\
\text { between } \\
\text { baseline and } \\
\text { after } 60 \text { min, } \\
\text { baseline and } \\
\text { peak BF in PPP }\end{array}$ & \\
\hline
\end{tabular}

ANOVA $=$ Analysis of Variance, ANCOVA $=$ Analysis of Covariance, BF $=$ Blood flow, $\mathrm{SP}=$ Systolic blood pressure, DP = Diastolic blood pressure, RAPS = Risk Assessment Pressure Ulcer Scale, $\mathrm{PU}=$ pressure ulcer, $\mathrm{PIV}=$ Pressure-induced vasodilation, $\mathrm{REP}=\mathrm{Nursing}$ staff-induced repositionings, $\mathrm{MOV}=$ Patients' spontaneous movements, $\mathrm{PPP}=$ post pressure period 
In Study III, a longitudinal linear mixed-method analysis was also performed to compare the blood flow responses between positions and tissue depths adjusted for patient characteristics, interface pressure, skin temperature, and time effect. The time when measurements were analysed (5-60 min) was treated as a random factor, and position, measurement depth, pulse, systolic and diastolic blood pressure, interface pressure, skin temperature, and body temperature were used as fixed factors. These variables were included to correct for potential confounding.

SPSS versions 18 (Study II), 20 (Study III) and 22 (Studies I and IV) (IBM SPSS Inc., Chicago, IL, USA) and STATA version 12.1 (Study III) (StataCorp LP, College Station, TX) were used to perform the statistical analysis.

\section{Ethical considerations}

The studies followed common ethical principles for clinical research regulated by the World Medical Association Declaration of Helsinki (WMA, 2008) and were approved by the Regional Ethical Review Board, Linköping, Sweden (D.nr. M 30-90, 2011/98-31, 2012/165-31). Participation was grounded on oral and written informed consent by either the patient or next of kin when appropriate. The patients were informed that participation was voluntary and that they could withdraw from the study whenever they wanted without giving any explanation. If the patient showed signs of not wanting to continue, the measurements were cancelled. The patients were guaranteed confidentiality maintained by coded study protocols. Code lists and protocols were stored separately and safely, and the personal information was handled according to Swedish law (1998:204). The university was the responsible organisation, and the patient was insured during their participation.

Patients in Study I might have found themselves limited and uncomfortable in some way simply with the knowledge that their movements were being observed and recorded. To minimize this potential feeling, they were told to behave as usual and not change anything in their movement pattern and that if they moved it would not disturb the measurements. The MiS device was developed for use in nursing care and is not in itself generally associated with discomfort. The adhesive dressing used to affix the transmitter to the skin was gentle, and the nursing staff was told to inspect the skin around the adhesive regularly. 
The methods used in Studies II-IV were all non-invasive and were not associated with discomfort or pain. The positions evaluated are commonly used in nursing praxis. However, to be positioned in many different positions within a short interval or lying still for up to one hour in the same position can be demanding, especially for an elderly person. To facilitate the participants, the position changes were carefully performed at the patients' own pace, and the patients were asked if they were comfortable and adjusted if necessary. In Study III, the number of positions evaluated was reduced from six to four so as not to be too strenuous for the participants. The potential risk for pressure ulcer development during the measurement was seen as small. The patient rested on a pressure-redistribution mattress, and the maximum loading time of one hour is regarded as short compared with recommended repostitioning frequencies. However, the skin was inspected after each measurement and if a redness did not fade within 15 minutes, this was reported to the nursing staff and was followed-up. No patients developed any pressure ulcers due to the measurements.

The measurements in Studies II-IV had the potential to conflict with the patients' daily activities or treatments. Therefore, the times for the measurement sessions were always planned in collaboration with the patient and the staff at the ward. In Study II, specific considerations were taken for patient safety because the patients had to be brought to a separate laboratory room outside the ward. Medical approval from the responsible physician was given before the patient left the ward, and the measurements were always made with two persons in the laboratory, a registered nurse (the author) and an assistant/registered nurse who was able to take actions in case of acute illness. No patients became ill during the measurements. 


\section{RESULTS}

Clinical characteristics, most common diseases, and medications for the patients in the different studies are presented in Table 4 . The age in the samples ranged between 65 and 98 years. There were no differences between sexes concerning clinical characteristics in the different study samples and, therefore, the values are reported together. There was only one smoker in the studies (Study III).

In Study I, twelve of the patients had an existing pressure ulcer, including four category 2 , one category 3 , and seven category 4 ulcers. The ulcers were located on either the sacrum or the heels. The mattresses in use, the most common prevention aids, and the pre-planned repositioning intervals in Study I are presented in Table 5. In Studies III and IV, the room temperature, the patients mean systolic and diastolic blood pressure, pulse, and body temperature did not differ between the measurement sessions. In comparing the PIV group and the non-PIV group, there was a significant difference in regards to pulse $(p=0.037)$ and number of medications named "others" ( $p=$ 0.001), of which drugs for acid-related disorders and mineral supplements were most common in the PIV group.

Table 4. Characteristics of the patients in the studies and their most common diseases and medications. Values are shown as the mean and standard deviation (SD) or as the number (n) and percentage (\%).

\begin{tabular}{|c|c|c|c|c|c|}
\hline & \multirow{3}{*}{$\begin{array}{l}\text { Study I } \\
(N=52)\end{array}$} & \multirow{3}{*}{$\begin{array}{l}\text { Study II } \\
(N=20)\end{array}$} & \multirow{3}{*}{$\begin{array}{l}\text { Study III } \\
(N=25)\end{array}$} & \multicolumn{2}{|c|}{ Study IV } \\
\hline & & & & $(N=11)$ & $(N=7)$ \\
\hline & & & & $\begin{array}{l}\text { PIV } \\
\text { group } \\
\text { mean } \\
(\mathrm{SD})\end{array}$ & $\begin{array}{l}\text { Non-PIV } \\
\text { group } \\
\text { mean } \\
(\mathrm{SD})\end{array}$ \\
\hline Age (years) & $85(7.3)$ & $84(7.5)$ & $85(7.3)$ & $86.5(5.5)$ & $90.3(4.8)$ \\
\hline $\operatorname{BMI}\left(\mathrm{kg} / \mathrm{m}^{2}\right)$ & $26(5.3)$ & $23(3.5)$ & $25(4)$ & $25(3.3)$ & $25(4.5)$ \\
\hline Heart rate (bpm) & - & $69(8)$ & $67(10)^{a}$ & $70(9)^{a}$ & $61(6)^{a, *}$ \\
\hline $\mathrm{SP}(\mathrm{mmHg})$ & - & $118(21)$ & $129(18)^{a}$ & $131(18)^{a}$ & $129(15)^{a}$ \\
\hline $\mathrm{DP}(\mathrm{mmHg})$ & - & $56(13)$ & $68(11)^{a}$ & $69(13)^{a}$ & $69(10)^{a}$ \\
\hline MAP (mmHg) & - & $76(3)$ & $88(11.4)^{\text {a }}$ & $90(13.6)^{a}$ & $89(8.8)^{a}$ \\
\hline Body temperature $\left({ }^{\circ} \mathrm{C}\right)$ & - & $36.5(0.5)$ & $36.2(0.4)^{a}$ & $36.2(0.4)^{a}$ & $36.1(0.5)^{\mathrm{a}}$ \\
\hline RAPS score & $24(3.1)$ & $31(3.5)$ & $30(3.5)$ & $30(3.4)$ & $30(4.7)$ \\
\hline $\begin{array}{l}\text { Number of } \\
\text { medications/patient }\end{array}$ & $7(3.3)$ & $6.2(2.9)$ & $6.4(3.2)$ & $6.4(2.3)$ & $5.0(2.3)$ \\
\hline
\end{tabular}




\begin{tabular}{|c|c|c|c|c|c|}
\hline & \multirow{4}{*}{$\begin{array}{l}\text { Study I } \\
(N=52)\end{array}$} & \multirow{4}{*}{$\begin{array}{l}\text { Study II } \\
(N=20)\end{array}$} & \multirow{4}{*}{$\begin{array}{l}\text { Study III } \\
(N=25)\end{array}$} & \multicolumn{2}{|c|}{ Study IV } \\
\hline & & & & $(N=11)$ & $(N=7)$ \\
\hline & & & & PIV & Non-PIV \\
\hline & & & & group & group \\
\hline & $n(\%)$ & $n(\%)$ & $n(\%)$ & $n(\%)$ & $n(\%)$ \\
\hline Women & $33(64)$ & $10(50)$ & $12(48)$ & $6(54)$ & $3(43)$ \\
\hline PU risk patients (RAPS $\leq 29 p$ ) & $52(100)$ & $5(25)$ & $13(52)$ & $5(45)$ & $3(43)$ \\
\hline Underweight (BMI < 22) & $8(23)$ & $5(25)$ & $5(21)$ & $2(18)$ & $1(14)$ \\
\hline Normal weight (BMI 22-29) & $19(54)$ & $13(65)$ & $16(67)$ & $8(73)$ & $5(72)$ \\
\hline Over weight (BMI > 29) & $8(23)$ & $2(10)$ & $3(12)$ & $1(9)$ & $1(14)$ \\
\hline \multicolumn{6}{|l|}{ Diseases } \\
\hline Cancer & 14 & 3 & 2 & 2 & - \\
\hline Cardiovascular disease & 26 & 9 & 12 & 7 & 3 \\
\hline Cerebrovascular disease & 14 & 4 & 10 & 4 & 4 \\
\hline Cognitive dysfunction & 17 & - & 5 & 2 & 1 \\
\hline Diabetes & 12 & 4 & 6 & 2 & 1 \\
\hline Hip fracture & 5 & - & 6 & 3 & 1 \\
\hline Hypertension & 21 & 10 & 9 & 5 & 3 \\
\hline Muscle/joint disease & 9 & 1 & 3 & 3 & - \\
\hline Parkinson's disease & 4 & - & 2 & 2 & - \\
\hline Pulmonary dysfunction & 13 & 1 & 5 & 1 & 1 \\
\hline \multicolumn{6}{|l|}{ Cardiac medications (ATC-reg) } \\
\hline Antithrombotic agents (B01) & 31 & 16 & 17 & 7 & 5 \\
\hline ACE-inhibitors (C09) & 8 & 9 & 8 & 3 & 2 \\
\hline Beta blocking agents (C07) & 24 & 10 & 13 & 4 & 4 \\
\hline $\begin{array}{l}\text { Calcium channel blockers } \\
\text { (C08) }\end{array}$ & 2 & 8 & 2 & 1 & 1 \\
\hline Cardiac therapy (C01) & 7 & 5 & 6 & 2 & 2 \\
\hline Diuretics (C03) & 20 & 5 & 11 & 7 & 2 \\
\hline \multicolumn{6}{|l|}{ Other systemic medications } \\
\hline Analgesics (N02) & 30 & 12 & 10 & 5 & 3 \\
\hline Antibacterial (J01) & 13 & 2 & - & - & - \\
\hline Anti anemics (B03) & 24 & 8 & 10 & 4 & 2 \\
\hline Antiepileptic (N03) & 10 & 2 & 1 & - & 1 \\
\hline Corticosteroids (H02) & 11 & 1 & 1 & - & 1 \\
\hline Lipid modifying agents (C10) & 7 & 8 & 5 & 2 & 1 \\
\hline Psychoanaleptics (N06) & 21 & 1 & 12 & 7 & 1 \\
\hline Psycholeptics (N05) & 18 & 8 & 8 & 4 & 2 \\
\hline Others & 41 & 10 & 21 & 10 & $4^{* * *}$ \\
\hline
\end{tabular}

${ }^{a}$ Mean value based on the $0^{\circ}$ supine position measurement session.

* The heart rate was significantly different from the PIV group $(p=0.037)$

*** Number of other medications was significantly different from the PIV group $(p=0.001)$ $\mathrm{PIV}=$ Pressure-induced vasodilation, $\mathrm{SP}=$ Systolic blood pressure, $\mathrm{DP}=$ Diastolic blood pressure, $\mathrm{MAP}=$ Mean arterial pressure, RAPS $=$ Risk Assessment Pressure Ulcer Scale, PU = pressure ulcer 
Table 5. Pressure prevention aids in use and pre-planned repositioning intervals in bed and chair among patients with and without pressure ulcers (Study I).

\begin{tabular}{|c|c|c|c|}
\hline & $\begin{array}{l}\text { No pressure } \\
\text { ulcer, } N=40 \\
n(\%)\end{array}$ & $\begin{array}{l}\text { Pressure } \\
\text { ulcer, } N=12 \\
n(\%)\end{array}$ & $\begin{array}{l}\text { Total, } \\
N=52 \\
n(\%)\end{array}$ \\
\hline \multicolumn{4}{|l|}{ Pressure prevention aids } \\
\hline Powered air fluid mattress & $10(25)$ & $7(58)$ & $17(33)$ \\
\hline Non-powered pressure-redistribution mattress & $21(52)$ & $4(33)$ & $25(48)$ \\
\hline Pressure-redistribution cushion in chair & $15(38)$ & $7(58)$ & $25(48)$ \\
\hline Positioning pillows & $18(45)$ & $3(25)$ & $18(35)$ \\
\hline Heel protection & $7(18)$ & $7(58)$ & $10(19)$ \\
\hline Slide sheet & $27(68)$ & $3(25)$ & $34(65)$ \\
\hline \multicolumn{4}{|l|}{ Pre-planned repositioning in bed } \\
\hline Hourly & $4(10)$ & $2(17)$ & $6(11)$ \\
\hline Every second hour & $1(2)$ & - & $1(2)$ \\
\hline Every third hour & $8(20)$ & $2(17)$ & $10(19)$ \\
\hline Every fourth hour & $3(8)$ & - & $3(6)$ \\
\hline Individually planned & $13(32)$ & $4(33)$ & $17(33)$ \\
\hline Not planned & $11(28)$ & $4(33)$ & $15(29)$ \\
\hline \multicolumn{4}{|l|}{ Pre-planned repositioning in chair } \\
\hline Hourly & $3(8)$ & $2(17)$ & $5(10)$ \\
\hline Every second hour & $3(8)$ & - & $3(6)$ \\
\hline Every third hour & $1(2)$ & - & $1(2)$ \\
\hline Every fourth hour & $2(5)$ & $1(8)$ & $3(6)$ \\
\hline Individually planned & $7(18)$ & $3(25)$ & $10(19)$ \\
\hline Not planned & $11(27)$ & $4(33)$ & $15(29)$ \\
\hline
\end{tabular}

\section{Repositioning in practice}

\section{Nursing staff-induced repositioning}

The nursing staff repositioned the patients a median of $5(\min 3, \max 9)$ times per day and $2(\min 0, \max 5)$ times per night $(p<0.001$, Study I). The time between repositionings ranged from 15 minutes to 14 hours and 24 minutes (median 3 hours and 12 minutes, Table 6). During the day, patients were in most cases repositioned to a sitting position in a chair or wheelchair $(31 \%, p \leq 0.003)$ or to a semi-Fowler position $>20^{\circ}$ in bed $(23 \%, p \leq 0.006)$ (Table 7 , Study I). 
Table 6. Descriptive statistics of nursing staff repositioning (REP) frequency and patients' spontaneous movements (MOV) registered by MovinSense (Study I).

\begin{tabular}{|c|c|c|c|}
\hline Variables & $N$ & Median (IQR) & Min-Max \\
\hline \multicolumn{4}{|l|}{ Nursing staff repositionings } \\
\hline Number of REP during the day & 50 & $5(2)$ & $3-9$ \\
\hline Number of REP during the night & 52 & $2(1)$ & $0-5$ \\
\hline Duration between repositionings (h:min) & 52 & $03: 12(1: 15)$ & $00: 15-14: 24$ \\
\hline \multicolumn{4}{|l|}{ Duration in different positions (h:min): } \\
\hline $0^{\circ}$ Supine & 44 & $02: 56(1: 36)$ & $00: 15-14: 24$ \\
\hline$>20^{\circ}$ semi-Fowler & 42 & $2: 30(1: 49)$ & $00: 15-11: 45$ \\
\hline $30^{\circ}$ Lateral & 42 & $03: 24(1: 11)$ & 00:20-13:30 \\
\hline $60^{\circ}$ Lateral & 29 & $03: 29(2: 30)$ & $00: 45-12: 40$ \\
\hline $90^{\circ}$ Lateral & 26 & $03: 30(2: 11)$ & 00:15-09:00 \\
\hline Sitting in chair/wheelchair & 38 & 02:20 (1:59) & 00:24-14:02 \\
\hline \multicolumn{4}{|l|}{ Spontaneous movements } \\
\hline Number of MOV during the day & 50 & $16(45)$ & $0-168$ \\
\hline Number of MOV during the night & 52 & $10(29)$ & $0-135$ \\
\hline Duration in same position and angle (h:min) & 52 & $00: 23(00: 32)$ & $00: 00^{a}-14: 18$ \\
\hline \multicolumn{4}{|l|}{ Number of MOV in: } \\
\hline $0^{\circ}$ Supine & 44 & $2(2)$ & $0-36$ \\
\hline$>20^{\circ}$ semi-Fowler & 42 & $4(7)$ & $0-33$ \\
\hline $30^{\circ}$ Lateral & 42 & $4(10)$ & $0-78$ \\
\hline $60^{\circ}$ Lateral & 29 & $3(8)$ & $0-34$ \\
\hline $90^{\circ}$ Lateral & 26 & $6(17)^{*}$ & $0-56$ \\
\hline Sitting in chair/wheelchair & 38 & $4(9)^{* *}$ & $0-106$ \\
\hline
\end{tabular}

$\mathrm{a}=6$ seconds

Two-way ANOVA analysis with Tukey's test for post hoc comparison:

* significantly different from $0^{\circ}$ supine, $>20^{\circ}$ semi-Fowler, and $60^{\circ}$ lateral position $(p \leq$ $0.043),{ }^{* *}$ significantly different from $0^{\circ}$ supine position $(p=0.006)$

Table 7. Number and percentage of total nursing staff-induced repositionings into the different positions during the day and the night.

\begin{tabular}{lllll}
\hline & Day & Night & $p$-value ${ }^{\text {a }}$ & Total \\
\hline $0^{\circ}$ supine & $68(15)$ & $77(24)$ & $<0.001$ & $145(19)$ \\
$>20^{\circ}$ semi-Fowler & $108(23)$ & $51(16)$ & 0.011 & $159(20)$ \\
Sitting in chair/wheelchair & $145(31)$ & $11(3)$ & $<0.001$ & $156(20)$ \\
$30^{\circ}$ lateral & $73(16)$ & $103(32)$ & $<0.001$ & $176(23)$ \\
$60^{\circ}$ lateral & $37(8)$ & $49(15)$ & 0.001 & $86(11)$ \\
$90^{\circ}$ lateral & $30(7)$ & $29(9)$ & NS & $59(8)$ \\
$\quad$ Total occasions & $461(100)$ & $320(100)$ & & $781(100)$ \\
\hline
\end{tabular}

${ }^{a}$ Compared to total occasions during the day and the night, respectively 
During the night, the $30^{\circ}$ lateral position and the $0^{\circ}$ supine position were more commonly used compared to the other positions $(p \leq 0.01)$. Overall, the $60^{\circ}$ lateral position and the $90^{\circ}$ lateral position were used to a lesser extent than the other positions $(p \leq 0.001)$.

During the daytime, the REP frequency correlated with having a pressure ulcer $(r=.279, p=0.05)$. During the nighttime, the REP frequency was significantly positively correlated with hospital care such as having a cancer diagnosis, while use of a slide sheet, total RAPS score, three of the RAPS variables (general health, activity, and moisture), having a cognitive dysfunction, and taking a psycholeptic medication were significantly negatively correlated (Table 8). The multiple regression model, built on variables significantly correlated to nighttime REP, explained $31 \%$ of the variance of REP $(\mathrm{F}(4,51)=6.7, p=<0.001)$. The total RAPS score $(p=0.021)$, cancer $(p=0.028)$, cognitive dysfunction $(p=0.036)$, and psycholeptics $(p=0.045)$ were independently related to REP.

\section{Patient spontaneous movements}

The patients moved spontaneously a median of 16 (IQR 45.0) times during the day and 10 (IQR 29.3) times during the night ( $p=0.012$, Study I). The number of spontaneous movements ranged between 0 and 168 during the day and between 0 and 135 during the night (Table 6). The duration spent in the same position and angle varied from 6 seconds to a maximum of 14 hours and 18 minutes (median 23 minutes, IQR 32 minutes). The MOV frequency was significantly different between positions $(\mathrm{F}(5,164)=2.43, p=0.037)$ and patients $(\mathrm{F}(51,164)=4.17, p<0.001)$. The patients made significantly more MOVs in the $90^{\circ}$ lateral position than in the $0^{\circ}$ supine, $>20^{\circ}$ semi-Fowler, and $60^{\circ}$ lateral positions (Table 6). They also made significantly more MOVs when sitting in a chair or wheelchair compared to lying in the $0^{\circ}$ supine position.

Having a muscle and or joint disease was negatively correlated with MOV frequency during the day $(r=-.359, p=0.010)$. During the night, analgesics and the friction and shear variable in the RAPS scale were positively correlated with MOV frequency, and taking psycholeptics was negatively correlated (Table 8). When entered in the multiple regression analysis, these variables explained $29 \%$ of the variance in MOV during the night $(F(3,48)=8.0, p=0.001)$. Analgesics $(p$ $=0.001)$ and psycholeptics $(p=0.017)$ were independently related to MOV frequency. 
Table 8. Correlation coefficients of nursing staff-induced repositioning (REP) frequency and patients' spontaneous movement (MOV) frequency during the night in relation to background data and clinical characteristics.

\begin{tabular}{lrr}
\hline & REP & MOV \\
\hline MOV & .055 & - \\
Type of healthcare a & $.468^{* *}$ & .129 \\
Gender & .088 & -.250 \\
Body Mass Index & .131 & .153 \\
RAPS score & $-.352^{*}$ & -.041 \\
RAPS subcategory General health & $-.405^{* *}$ & -.081 \\
RAPS subcategory Mobility & .145 & .220 \\
RAPS subcategory Activity & $-.384^{* *}$ & .133 \\
RAPS subcategory Moisture & $-.372^{* *}$ & -.167 \\
RAPS subcategory Friction \& Shear & .165 & $.368^{* *}$ \\
RAPS subcategory Food Intake & -.236 & -.017 \\
RAPS subcategory Sensory Perception & .126 & -.038 \\
Existing pressure ulcer & .089 & .160 \\
Pre-planned repositioning in bed & .087 & - \\
Mattress ${ }^{b}$ & -.137 & .129 \\
Slide sheet & $-.345^{*}$ & -.187 \\
Cognitive dysfunction & $-.354^{*}$ & -.011 \\
Cerebrovascular disease & .082 & -.009 \\
Cancer & $.374^{* *}$ & -.061 \\
Muscle/joint disease & .106 & -.130 \\
Parkinson's disease & .007 & .012 \\
Hip fracture & -.151 & .137 \\
Analgesics & .085 & $.350^{*}$ \\
Psychoanaleptics & -.122 & .090 \\
Psycholeptics & $-.282^{*}$ & $-.298^{*}$ \\
\hline Correlation is signicant at the 0.05 & & \\
\hline
\end{tabular}

* Correlation is significant at the 0.05 level (2-tailed).

** Correlation is significant at the 0.01 level (2-tailed).

a Municipality $=0$; Hospital $=1$

b Powered air fluid mattress $=1$; Non-powered pressure-redistribution mattress $=$ 2; Standard mattress $=3$

RAPS $=$ Risk Assessment Pressure Ulcer Scale 


\section{The effects of different lying positions}

\section{Effects on interface pressure}

The mean interface pressure was highest in the $90^{\circ}$ lateral position $(48.4 \pm 16.3$ $\mathrm{mmHg}$ ) and in the $0^{\circ}$ supine position $(44.7 \pm 11.7 \mathrm{mmHg}$ ) (Study III). The interface pressures in these two positions were higher compared to the mean interface pressures for the $30^{\circ}$ supine tilt position and the $30^{\circ}$ lateral position, which were $32.9 \pm 9.1 \mathrm{mmHg}$ and $29.5 \pm 10.4 \mathrm{mmHg}$, respectively $(\mathrm{F}(3,48)=$ $11.5, p<.001)$. The interface pressure was not evaluated in the semi-Fowler positions (Study II). The interface pressure measured in $0^{\circ}$ supine and $30^{\circ}$ supine tilt position did not differ between the PIV and non-PIV group (Study IV).

\section{Effects on skin temperature}

In Study II, the skin temperature increased from the first baseline measurement to the last position at each study site by $2.4^{\circ} \mathrm{C}$ over the sacrum, $1.4{ }^{\circ} \mathrm{C}$ over trochanter major, and $2.2{ }^{\circ} \mathrm{C}$ over gluteus maximus. Thus, the skin temperature differed between the positions over the sacrum and trochanter major $(\mathrm{F}(1.3,23.2)=33.5, p<0.001)$ and the gluteus maximus muscle $(\mathrm{F}(2.1,38.1)$ $=107.3, p<0.001)$.

The skin temperature also increased over the 60 minutes of loading in Study III by an average of $2.7-3.2^{\circ} \mathrm{C}$ (Figure 8 ). The skin temperature at baseline was lower over the trochanter major in the $30^{\circ}$ lateral position $\left(31.9 \pm 1.5^{\circ} \mathrm{C}\right)$ and in the $90^{\circ}$ lateral position $\left(31.8 \pm 1.3^{\circ} \mathrm{C}\right)$ than over sacrum in the $0^{\circ}$ supine position $\left(33.0 \pm 1.1{ }^{\circ} \mathrm{C}\right)$ and in the $30^{\circ}$ tilt position $\left(33.1 \pm 0.8^{\circ} \mathrm{C}\right)(\mathrm{F}(1.5,29.9)=14.0, p<$ $0.001)$. The difference between the sacrum and trochanter major remained until the end of the 60 minutes of loading $(\mathrm{F}(3,27)=9.7, p<0.001)$.

The skin temperature increased in average of $2.9-3.1^{\circ} \mathrm{C}$ in the PIV group and $2.2-2.9^{\circ} \mathrm{C}$ in the non-PIV group, but the skin temperature did not differ between the two groups at either baseline or after 60 minutes (Study IV). 


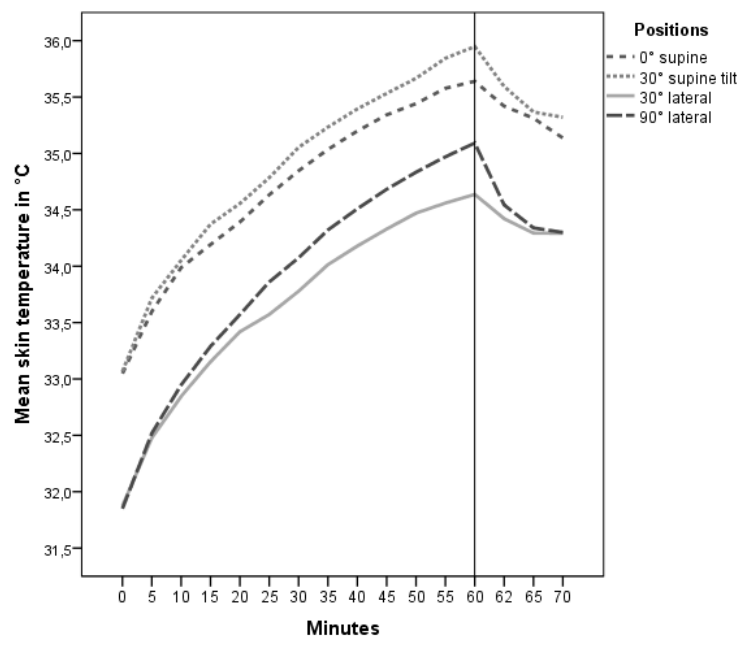

Figure 8. Mean skin temperature from baseline (0 min), when loaded (5-60 min), and in an unloaded position (62-70 min) over the sacrum in the $30^{\circ}$ and $0^{\circ}$ supine positions and over the trochanter major in the $30^{\circ}$ and $90^{\circ}$ lateral positions. The vertical line indicates the moment when the patients were repositioned to unload the tissue again (Study III).

\section{Effects on blood flow}

The most common pattern at the group level in Studies II and III was an increase in median blood flow in the positions at all tissue depths and areas (Figure 9, Table 9, Figure 10). A significant decrease was only seen in the $30^{\circ}$ lateral position at $2 \mathrm{~mm}$ depth over the trochanter major in Study II (Figure 9). There were large variations in blood flow during loading.

In the post-pressure period, the peak blood flow at the group level remained significantly higher compared to baseline in almost all positions and tissue depths, but the peak blood flow was not significantly higher than after 60 minutes of load in any position or tissue depth (Figure 10, Table 9) (Study III).

At an individual level, the typical pattern of blood flow was a distinct response that appeared early and remained throughout the 60-minute loading period (Figure 11, Study IV). In the PIV group, the blood flow increased in almost all cases within 10-15 minutes and remained over baseline for the entire 60 minutes, while the blood flow decreased immediately and remained below baseline in the non-PIV group. 


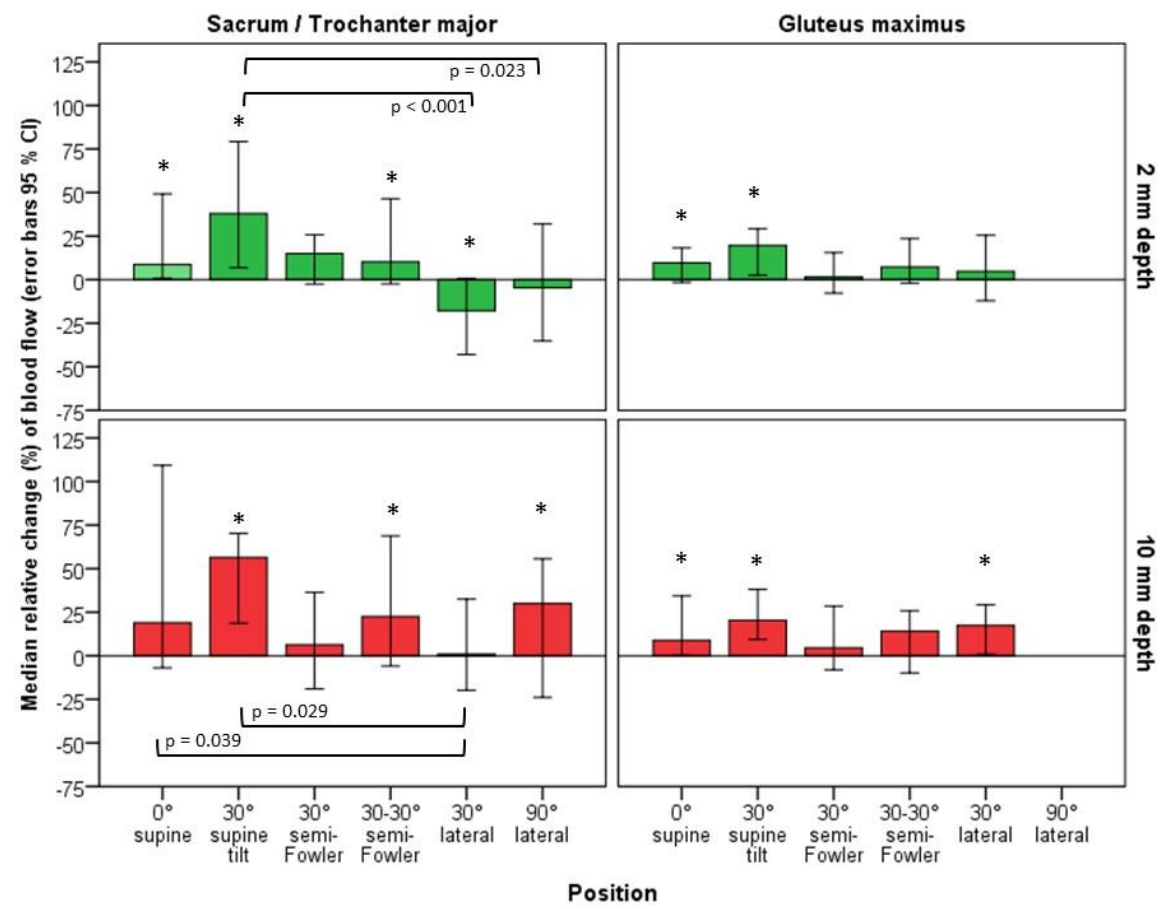

Figure 9. Median blood flow responses in different positions over the sacrum (all supine and semi-Fowler positions) or the trochanter major (lateral positions) at $2 \mathrm{~mm}$ and $10 \mathrm{~mm}$ depths (Study II). The braces indicate significant differences between positions and the related p-values derived from the post-hoc test of the ANCOVA model 1. The asterisks indicate significant difference in blood flow compared to baseline, $p$-value $<0.05$. 


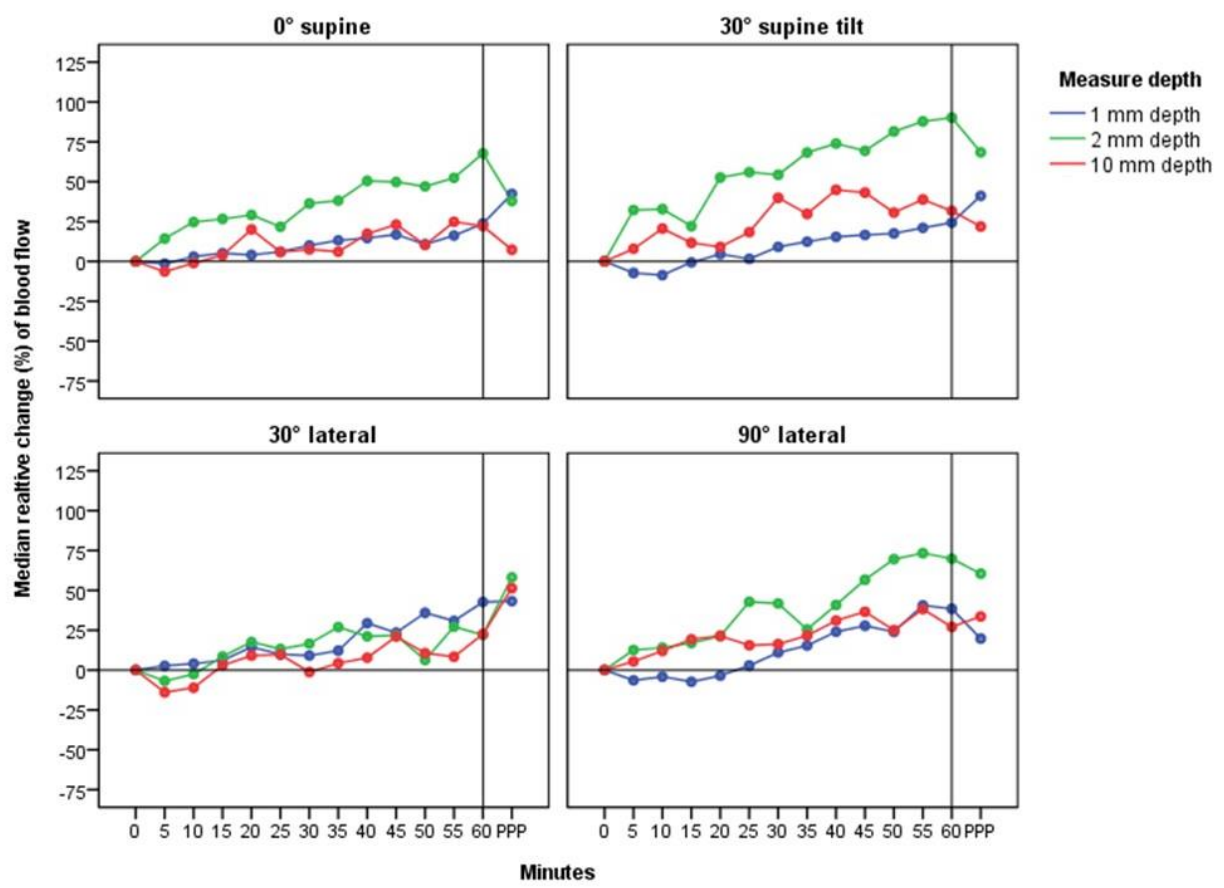

Figure 10. Median relative change (\%) in blood flow at approximately $1 \mathrm{~mm}, 2 \mathrm{~mm}$, and 10 $\mathrm{mm}$ tissue depths when loaded (5-60 min) in the $0^{\circ}$ supine and $30^{\circ}$ supine tilt position (sacrum loaded) and $30^{\circ}$ and $90^{\circ}$ lateral positions (trochanter major loaded), and in the peak blood flow in the post-pressure period (PPP; 62-70 min). The horizontal line indicates the baseline value, and the vertical line indicates blood flow responses just before offloading at 60 minutes. 
Table 9. Relative change (\%) in blood flow (BF) from baseline to 60 minutes of loading and from baseline to the peak blood flow in the post-pressure period at $1 \mathrm{~mm}, 2 \mathrm{~mm}$, and $10 \mathrm{~mm}$ depths in the different positions in Study III.

\begin{tabular}{|c|c|c|c|c|c|c|c|c|c|c|}
\hline \multirow[t]{2}{*}{ Position } & \multirow[t]{2}{*}{ Depth } & \multicolumn{3}{|c|}{$\mathrm{BF}$ at $60 \mathrm{~min}$} & \multicolumn{6}{|c|}{ Peak BF in PPP } \\
\hline & & $\mathrm{Md}$ & IQR & Mean & $\begin{array}{r}p- \\
\text { value }\end{array}$ & Md & IQR & Mean & $\begin{array}{r}p- \\
\text { value }^{\text {a }}\end{array}$ & $\begin{array}{r}p- \\
\text { value }^{\mathrm{b}}\end{array}$ \\
\hline \multirow[t]{3}{*}{$0^{\circ}$ supine } & $1 \mathrm{~mm}$ & 23.7 & 110.0 & 43.1 & NS & 42.3 & 117.5 & 89.8 & .025 & NS \\
\hline & $2 \mathrm{~mm}$ & 67.7 & 77.6 & 77.4 & $<.001$ & 37.9 & 74.7 & 32.3 & .001 & 0.006 \\
\hline & $10 \mathrm{~mm}$ & 22.1 & 101.1 & 37.9 & .004 & 7.3 & 53.9 & 15.2 & NS & NS \\
\hline $30^{\circ}$ supine & $1 \mathrm{~mm}$ & 24.3 & 67.9 & 23.1 & NS & 41.2 & 83.6 & 39.1 & .006 & NS \\
\hline \multirow[t]{2}{*}{ tilt } & $2 \mathrm{~mm}$ & 90.2 & 90.3 & 102.7 & .001 & 68.4 & 87.4 & 65.9 & .010 & NS \\
\hline & $10 \mathrm{~mm}$ & 31.7 & 65.7 & 51.2 & NS & 21.9 & 79.2 & 39.1 & NS & NS \\
\hline \multirow[t]{3}{*}{$30^{\circ}$ lateral } & $1 \mathrm{~mm}$ & 42.7 & 142.0 & 79.0 & .001 & 43.2 & 59.3 & 86.2 & .002 & NS \\
\hline & $2 \mathrm{~mm}$ & 22.1 & 65.2 & 27.5 & .026 & 58.2 & 77.4 & 68.1 & .006 & NS \\
\hline & $10 \mathrm{~mm}$ & 22.6 & 70.4 & 28.8 & .041 & 51.4 & 73.6 & 53.2 & .003 & NS \\
\hline \multirow[t]{3}{*}{$90^{\circ}$ lateral } & $1 \mathrm{~mm}$ & 38.4 & 74.9 & 50.7 & .021 & 19.8 & 145.2 & 103.4 & .007 & NS \\
\hline & $2 \mathrm{~mm}$ & 69.9 & 135.4 & 35.0 & .001 & 60.5 & 115.6 & 9.1 & $<.001$ & NS \\
\hline & $10 \mathrm{~mm}$ & 27.1 & 69.6 & 34.5 & .004 & 33.7 & 108.0 & 52.6 & .006 & NS \\
\hline
\end{tabular}

a Compared to baseline, ${ }^{\mathrm{b}}$ Compared to the blood flow after 60 minutes of load

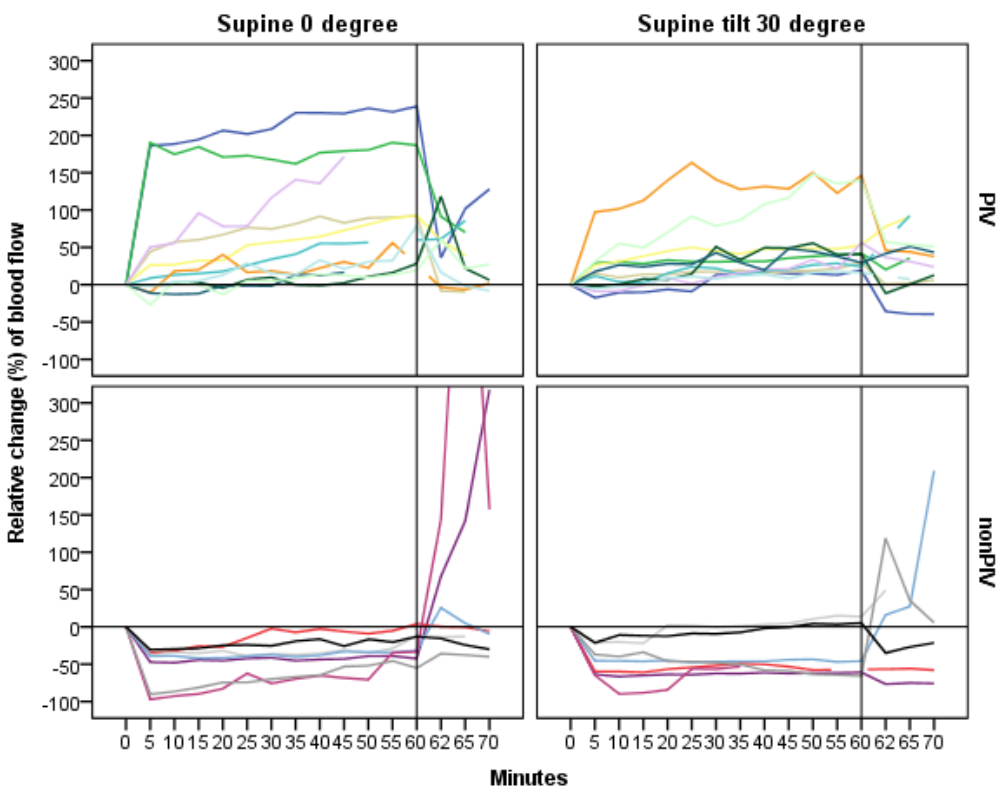

Figure 11. Relative change (\%) of blood flow in the groups with pressure-induced vasodilation (PIV) and with non-PIV at $1 \mathrm{~mm}$ depth when loaded (5-60 min) and in the post-pressure period (62-70 min) in $0^{\circ}$ supine position and $30^{\circ}$ supine tilt position (Study IV). The horizontal line indicates the baseline ( 0$)$ value and the vertical line indicates blood flow responses just before offloading at 60 minutes. 
In Study II, the ANCOVA (model 1) showed significant differences between positions over the sacrum and trochanter major at both $2 \mathrm{~mm}$ depth $(\mathrm{F}(5,86)=$ $4.8, p=0.001)$ and $10 \mathrm{~mm}$ depth $(\mathrm{F}(5,80)=4.1, p=0.002)$. The blood flow at 2 $\mathrm{mm}$ depth was significantly higher in the $30^{\circ}$ supine tilt position than in the $30^{\circ}$ lateral and $90^{\circ}$ lateral position (Figure 9). At $10 \mathrm{~mm}$ depth, the blood flow was significantly higher in the $0^{\circ}$ supine and $30^{\circ}$ supine tilt positions compared to the $30^{\circ}$ lateral position. There was no significant difference in blood flow between the positions over the gluteus muscle area at either tissue depth.

The longitudinal mixed-effects model in Study III showed that the overall blood flow response was significantly higher in the $30^{\circ}$ supine tilt position compared to the $0^{\circ}$ supine position and the $30^{\circ}$ and $90^{\circ}$ lateral positions during the 60 minutes of loading (Table 10). The same model, but with comparisons between positions at each tissue depth, showed that the blood flow at $1 \mathrm{~mm}$ depth was significantly higher in the $0^{\circ}$ supine position compared to the other positions (Table 11). At the tissue depths of $2 \mathrm{~mm}$ and $10 \mathrm{~mm}$, the blood flow was significantly higher in the $30^{\circ}$ supine tilt position compared to the other positions. At the $10 \mathrm{~mm}$ depth, the blood flow in the $30^{\circ}$ lateral position was significantly lower compared to the other positions.

\section{Variables with effects on tissue blood flow during load}

Variables that affect blood flow were studied in different models. Model 1 (ANCOVA, Study II) confirmed that a significant difference in blood flow was present between patients at both $2 \mathrm{~mm}$ depth $(\mathrm{F}(19,86)=2.7, p 0.001)$ and 10 mm depth $(F(19,80)=3.1, p<0.001)$. Model 2 (ANCOVA, Study II) showed that the mean arterial pressure $(p=0.014)$ and body temperature $(p=0.011)$ had a significant effect on the blood flow at $2 \mathrm{~mm}$ depth.

In the longitudinal linear mixed model (Study III), the systolic blood pressure, interface pressure, body temperature, and loading time had a significant effect on the overall blood flow with a positive slope, and diastolic blood pressure and skin temperature had a significant effect with a negative slope (Table 10).

The comparison between the PIV group and non-PIV group showed that the PIV group had a significantly higher pulse compared to the non-PIV group (Table 4), but the difference was only significant between the groups in the $0^{\circ}$ supine position. 
Table 10. Comparison of mean blood flow responses between the positions and measurement depths, adjusted for position/measurement depths, time, interface pressure, skin temperature, and background data (Study III). Values represent the mean relative change in per cent, and 95\% confidence intervals (CI) are shown in parentheses.

Number of participants $=23$, observations $=2,434$

\begin{tabular}{ll}
\hline $30^{\circ}$ supine tilt as reference & Mean $(\mathbf{9 5} \% \mathbf{C I})$ \\
$0^{\circ}$ supine & $-14.6(-22.4,-6.8)^{* * *} \mathrm{~A}$ \\
$30^{\circ}$ lateral & $-19.8(-28.5,-11.1)^{* * *} \mathrm{~A}$ \\
$90^{\circ}$ lateral & $-21.1(-29.9,-12.3)^{* * *} \mathrm{~A}$ \\
& \\
$1 \mathrm{~mm}$ depth as reference & \\
2 mm depth & $24.2(18.7,29.7)^{* * *} \mathrm{~B}$ \\
$\geq 10$ mm depth & $3.8(-1.8,9.5)$ \\
& \\
Gender & $10.5(-7.8,28.9)$ \\
Age & $-0.8(-2.1,0.4)$ \\
Risk & $8.3(-11.8,28.3)$ \\
Pulse & $-0.2(-0.7,0.2)$ \\
Systolic blood pressure & $1.1(0.7,1.4)^{* * *}$ \\
Diastolic blood pressure & $-1.6(-2.1,-1.1)^{* * *}$ \\
Interface pressure & $1.1(0.9,1.4)^{* * *}$ \\
Skin temperature & $-4.8(-8.5,-1.2)^{* *}$ \\
Body temperature & $35.6(26.9,44.3)^{* * *}$ \\
Minutes & $1.1(0.8,1.3)^{* * *}$ \\
BMI & $-0.2(-2.4,1.9)$ \\
\hline
\end{tabular}

*** $p<0.001$

** $p<0.01$

A) Significantly lower blood flow in comparison to the $30^{\circ}$ supine tilt position

B) Significantly higher blood flow in comparison to $1 \mathrm{~mm}$ depth 


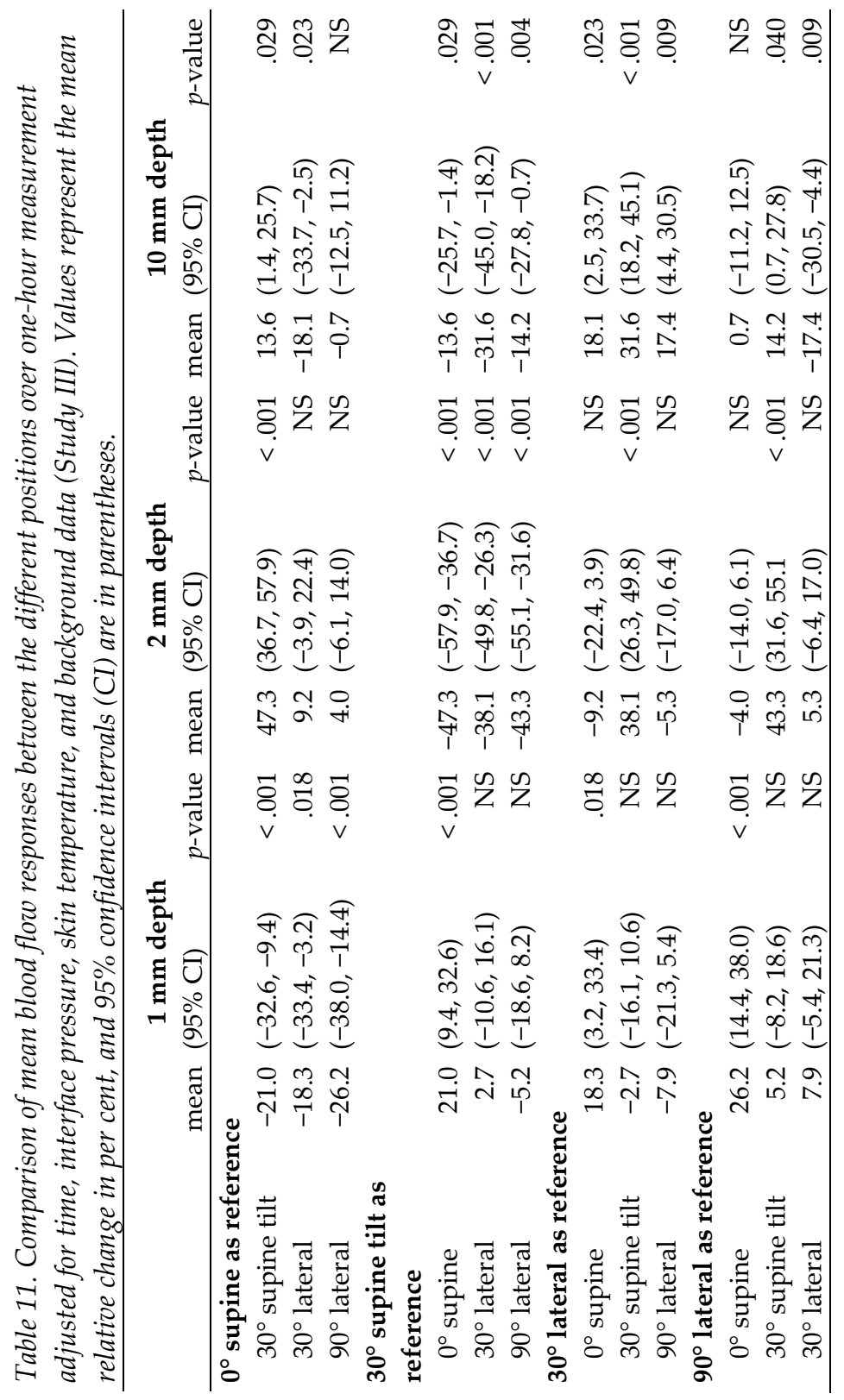




\section{DISCUSSION}

This thesis contributes with new knowledge on the repositioning patterns, including both nursing staff-induced and those spontaneously made by the patients, that appear in the ordinary day-to-day care of elderly immobile patients. Furthermore, this thesis brings new insights into how the tissue blood flow is affected by loading in different lying positions and at different tissue depths.

The main findings were that some of the elderly immobile patients made many spontaneous movements, while others did not; that the $30^{\circ}$ supine tilt position was the most beneficial of the positions evaluated from a tissue blood flow perspective; and that the elderly patients with non-PIV response had such a lack of response during the entire time of loading. What influences these and further findings might have on repositioning as a preventive intervention for pressure ulcer development will be discussed below.

\section{Repositioning in practice}

The results in Study I shows what of previous studies have indicated (Vanderwee et al., 2007; Young, 2004); that elderly immobilised patients perform spontaneous movements between nursing staff-induced repositionings, but to varying degrees. Based on the theory that pressure ulcers are mainly caused by ischemia, these movements, although minor, are of importance for redistributing pressure and promoting blood flow. Thus, it is reasonable to assume that patients who perform a large number of spontaneous movements might not need to be repositioned as often as those who do not. However, there was no significant correlation between the nursing staffinduced repositionings and the frequency of the patients' spontaneous movements either during the day or during the night. A possible explanation for this might be that there are ongoing activities, especially during the day, that influence the repositiong frequency. A further explanation might be that the nursing staff are not aware that the patients perform these minor movements and thus do not consider these when planning the repositioning frequency. 
Several factors were related to the frequency with which the nursing staff repositioned the patients during the night, and this indicated that the repositioning as an intervention was individualized. Of these factors, the patients' total RAPS scores were shown to have most impact on the REP frequency. Patients with a low total RAPS score, which indicates a high risk for pressure ulcer development, were associated with a higher frequency of repositionings than patients with higher scores, and this finding is in accordance with previous research (Johansen et al., 2014; Sving et al., 2014). However, the patients' MOV frequency was not related to the risk scores. This is an important finding because it implies that immobile patients assessed as low risk might still need to be repositioned as often as patients assessed as high risk.

Of the data collected in Study I, medications with analgesics and psycholeptics were found to be independently correlated to the MOV frequency; analgesics were positively correlated and psycholeptics were negatively correlated. Chronic pain is a major issue in the care of elderly patients, and in addition to causing a decreased quality of life, the pain might cause adverse effects such as sleep disturbances and immobility (Kamel \& Gammack, 2006; Won et al., 2006). The positive correlation between the use of analgesics and MOV frequency suggests that adequate pain relief is important in pressure ulcer prevention by increasing the patient's ability to move. Psycholeptics were associated with a decreased MOV frequency during the night. This is also an important finding because many elderly people are prescribed these medications. In our sample, 18 of 52 were taking this type of medication on a regular basis. It is noteworthy that these patients were also less frequently repositioned by the nursing staff. From a pressure ulcer prevention perspective, this is unfortunate because patients who are prescribed psycholeptics are more likely in need of being repositioned more frequently than others due to decreased MOV frequency.

Most of the patients had a pre-planned repositioning schedule, a pressureredistribution surface on their chair and bed, a slide sheet, and, in some cases, a heel protection aid. These interventions were performed as both primary and secondary preventions by the nursing staff. The patients were repositioned an average of five times during the day and two times during the night, which might reflect an individually planned repositioning schedule. However, Moore et al (2011) found that such an approach, with less frequent repositionings during the night, resulted in a higher incidence of pressure ulcers than a regular repositioning frequency of every three hours. Furthermore, the results of Study I showed that the interval between repositionings varied greatly and in some 
cases was unacceptably long. All patients were at risk for pressure ulcer development, were assessed as highly limited in their activity and mobility, and were in need of regularly repositioning. To not be helped to reposition for up to 14 hours is inhumane and is inconsistent with a holistic approach (Hawkins et al., 1999). This highlights the importance of having a structured approach and pre-planned individualised schedules that ensure that patients are repositioned within specified time intervals.

As recommended in pressure ulcer guidelines (NPUAP. et al., 2014), the $30^{\circ}$ lateral position was most often used when a side-lying position was appropriate. In previous clinical research, where different repositioning frequencies have been evaluated, this position has been noted to be unstable and not always well adopted among patients (Vanderwee et al., 2007; Young, 2004). Therefore, it was expected that the patients would perform more spontaneous movements in this position than in others, but this was not confirmed; the MOV frequencies in this position were more or less the same as in the other positions. Instead, an interesting finding was that the patients performed fewer spontaneous movements in the $0^{\circ}$ supine position. It is possible that this position is too stable, so the patients find it difficult to make minor movements by themselves (Spilsbury et al., 2007). Because patients tend to spend much time on their backs, this might be important to take into account because it contributes to increased pressure exposure over the same sites, especially over bony prominences such as the sacrum and heels.

\section{Evaluation of different lying positions}

Several positions were used in the patients' repositioning schedules (Study I), and a number of these were further evaluated in Studied II-IV. In addition to these, the $30^{\circ}$ supine tilt position was of special interest because to our knowledge this position has not previously been studied. The focus was on how the blood flow at different tissue depths was affected over weight-bearing areas in the different positions. The pilot study (Study II) showed that the lying positions influenced the tissue blood flow over the sacrum and trochanter major in different ways during load, which was further supported in the main study (Study III).

The longitudinal mixed-effect model (Study III) showed that the overall blood flow response during one hour of loading was significantly higher in the $30^{\circ}$ tilt position than in the $0^{\circ}$ supine, $30^{\circ}$ lateral, and $90^{\circ}$ lateral positions. The 
pressure itself, and the increased skin temperature observed during the measurement, requires a physiological vasodilation response to protect the tissue from ischemia (Fromy et al., 2012; Lachenbruch et al., 2015). Because the $30^{\circ}$ supine tilt position allowed the highest blood flow, this position was regarded as most beneficial from a tissue blood flow perspective.

The results in Study III showed that the interface pressure was significantly lower in the $30^{\circ}$ supine tilt and $30^{\circ}$ lateral positions compared to the $0^{\circ}$ supine and the $90^{\circ}$ lateral positions, which was expected. Both of these $30^{\circ}$ positions are thought to transfer the pressure from bony prominences to larger tissue masses and thus disperse the applied pressure. Although the interface pressure appeared to be similar in these two $30^{\circ}$ positions, the blood flow response in the $30^{\circ}$ lateral position was not as high as in the $30^{\circ}$ supine tilt position, either when comparing the overall blood flow (Study III) or at $2 \mathrm{~mm}$ and $10 \mathrm{~mm}$ depth (Studies II and III). This might be explained by anatomical differences between the sacrum and the trochanter major. Interestingly, and more surprisingly, the overall blood flow in the $30^{\circ}$ lateral position did not differ in comparison to the $90^{\circ}$ lateral position. In fact, at $10 \mathrm{~mm}$ depth the blood flow was significantly lower compared to the $90^{\circ}$ lateral position (Study III). These results contradict the findings of Seiler et al. (1986) and Colin et al. (1996) who both found a dramatic decrease in blood oxygenation when measured over the trochanter major in the $90^{\circ}$ lateral position while the oxygenation remained almost unchanged in the $30^{\circ}$ lateral position. There are, however, important methodological differences between their studies and the studies in this thesis. They measured the transcutaneous oxygen pressure $\left(\mathrm{TcPO}_{2}\right)$, which requires heating of the skin up to $44{ }^{\circ} \mathrm{C}$ and does not reflect normal heat accumulation. Furthermore, the $\mathrm{TcPO}_{2}$ sensors had a profile that undoubtedly interfered with the localized pressure and could, therefore, give false readings (Rithalia, 2005). The measurement probe used in this thesis was thin and flexible, and neither the silicon nor the light affect skin surface temperature (Hagblad, 2011). Furthermore, our results reflect the blood flow at different tissue depths and from a larger area by using PPG in combination with LDF. Our results do not support the statements by Seiler and Stähelin (1986) that "the $90^{\circ}$ lateral positioning must be banished as a preventive technique" or the guidelines that suggest that this position should be avoided (NPUAP et al., 2014). It is noteworthy that in clinical trials where the $90^{\circ}$ lateral position has been compared to the $30^{\circ}$ lateral position no patients treated in the $90^{\circ}$ lateral position developed pressure ulcers on their hip or shoulder (Moore et al., 2011; Young, 2004). However, further studies are needed to confirm the true effect from lying 
in these positions. The results in this thesis show that there is no great difference when resting on a pressure-redistribution mattress.

The blood flow at $10 \mathrm{~mm}$ depth was most affected over the sacrum in the $30^{\circ}$ semi-Fowler position with straight legs (Study II) and over the trochanter major in the $30^{\circ}$ lateral position (Studies II and III). This is an interesting finding because these two positions are considered to be somewhat unstable. If the legs are not elevated in the semi-Fowler position, the patient has a tendency to gradually slide down in the bed, which might cause shear forces (Harada et al., 2002). The same has been shown to occur in the $30^{\circ}$ lateral position; if the pillow behind the patient's back is not sufficiently supportive, the patient has a tendency to gradually slide down to a supine position (Vanderwee et al., 2007; Young, 2004). Thus, it is likely that these two positions involve a greater amount of shear forces than other positions. Furthermore, our sample consists of patients with advanced aged. In aged skin, more pronounced skin tissue displacements could take place due to reduced elasticity and turgor (Gerhardt et al., 2009). In addition, shear force affects mainly the microcirculation in the deeper tissue layers (Linder-Ganz \& Gefen, 2007; Stekelenburg et al., 2008), which might explain these results.

The variations in blood flow in all positions were greater over the sacrum and the trochanter major at both $2 \mathrm{~mm}$ and $10 \mathrm{~mm}$ depth than over the gluteus maximus muscle (Study II). This is in accordance with a study by Schubert and Fagrell (1989), who also found that the blood flow during load had a more stable pattern over the gluteus muscle area compared to over the sacrum. Schubert and Fagrell also found that the pressure was 2 to 2.4 times higher over the sacrum than over the gluteus maximus muscle, even though the pressure applied was the same. This supports the idea that the pressure is distributed over a larger tissue volume over the gluteus muscle than over the sacrum and thus effect the microcirculation to a lesser extent.

\section{Blood flow patterns during and after load}

The most common pattern at the group level in Studies II and III was an increase in median blood flow during load irrespective of position or tissue depths. However, the distributions of blood flow responses over the sacrum and the trochanter major were wide, indicating that some patients had a PIV response during load while others did not. Furthermore, the inter quartile range in the post-pressure period was also wide indicating that some patients might 
have had a reactive hyperaemic response due to ischemia. Therefore, it was of interest to characterize the individual PIV function, which was done based upon the LDF measurements in Study III in the $0^{\circ}$ supine and $30^{\circ}$ supine tilt positions. The $0^{\circ}$ supine position was chosen because the patients lay stable in this position, and the $30^{\circ}$ supine tilt position served as the reference. This in-depth analysis (Study IV) showed that the cutaneous blood flow response among the older patients was distinct, appeared early, and remained throughout the 60 minutes of loading in both the PIV and non-PIV group and in both the $0^{\circ}$ supine position and the $30^{\circ}$ supine tilt position. Thus the group lacking a PIV response had an insufficient blood flow almost immediately and that continued as long as pressure was sustained, which is a pattern linked to pressure ulcer development (Sanada et al., 1997). Furthermore, the patients lacking a PIV response seemed to have impaired ability to increase the blood flow in relation to the heat accumulation. The temperature increased in mean as much as $2.9^{\circ} \mathrm{C}$ during the one hour of loading in the non-PIV group, which according to findings by Lachenbruch et al. (2015) contributes to an ischemic response equivalent to approximately $40 \mathrm{mmHg}$ pressure. In addition, some of the patients in the non-PIV group did not have a marked reactive hyperaemic response when the pressure was relieved (Figure 9). A lack of these two proactive responses and less vasodilation due to heat stress might worsen the effect of ischemia and put these patients at even a higher risk for developing pressure ulcers (Bergstrand et al., 2014; Ek et al., 1987).

The results in Studies II-IV show that the blood flow response in a given situation is specific to the individual and not easy to predict, and this is in accordance with previous findings (Frantz et al., 1993). Likewise, no common trend in blood flow responses emerged among those patients identified as being at risk for pressure ulcer development in the different studies. However, early detection of patients at risk for pressure ulcer development is an important clinical issue, and patients with disturbed microcirculation might be particularly important to identify (Coleman et al., 2013; Wywialowski, 1999). Although immobility is regarded as the primary factor for pressure ulcer development, a lack of PIV and or reactive hyperaemia might explain why some immobile patients develop pressure ulcers while others do not (Coleman et al., 2014). The only physical factor, which emerged as significant between the PIV and non-PIV group, was the pulse, but this difference is probably not of clinical relevance since the beats per minute were within normal clinical margins in both groups and only significant in one of the two positions (i.e. occasions). However, several other factors were associated with either increased or decreased blood flow in the longitudinal mixed-effects model in Study III, but 
none of them were significant when comparing them between the PIV and nonPIV groups. This might be due to a small sample size, and thus further research is needed to confirm these results.

\section{Methodological considerations}

\section{Design and samples}

A strength of Study I was that the patients were recruited from different care settings and participated over several days such that different nursing teams repositioned the patients. Thus, a broad picture of how repositioning works in practice was captured. This design involved a large number of nursing staff that needed to be informed on how to how to fill in the study protocol for the repositionings. To ensure that the protocols were filled in as accurately as possible the following actions were taken: information was given at staff meetings before entrance of the study, the current working nursing team was informed by the researcher when the measurement would begin, the nursing team informed their colleagues, and the instructions were given in writing.

When the design for Study III was planned, the intention was to measure the blood flow over the course of two hours in each position so as to mimic the traditional two-hour repositioning frequency. However, the pilot study (Study II) suggested that measurements exceeding one hour were particular strenuous for the patients. The pilot study also showed that the skin temperature increase during the measurement has to be considered. Thus, because the skin temperature increase was shown to reach a plateau within 30-60 minutes using the same equipment (Hagblad et al., 2012), the one-hour interval was chosen.

Two positions were excluded from the study design in Study III. This was done due to apprehensions that the participants would not be able to fulfil all of the measurement occasions if there were too many of them. Because the $30^{\circ}$ supine tilt position was in focus, the positions that most likely could be replaced or combined with this position, especially during the nighttime, were kept. Thus, the semi-Fowler positions were excluded.

No obvious factor could be identified in Study IV that predicted a lack of PIV function within the group of elderly patients. This might be due to the small and relatively homogenous sample. Although the comparison between the groups not was the primary aim of the study, it could be of value for future 
investigations to capture a broader sample of patients with regard to age, diagnosis, and risk factors. The blood flow studies in this thesis could, however, form the basis for further hypothesis testing.

In Studies II-IV the blood flow measurements were taken over the areas of the sacrum, the trochanter major, and the gluteus maximus muscle. These sites were chosen because they are regarded as the most weight-bearing areas while resting in the evaluated positions (Colin et al., 1996; Defloor, 2000). Furthermore, the sacrum and trochanter major are known areas for pressure ulcers (Båăth et al., 2014). Because the heels are also common sites for pressure ulcers, it would have been of particular interest to evaluate how they are affected in the different positions. However, such measurements would have required a smaller type of measurement probe that was not available when the studies were planned and designed.

\section{Data analysis}

Several statistical analyses were chosen and performed depending on sample size, data level, and distribution of data (Field, 2009). The REP, MOV, and blood flow data were not normally distributed and thus were presented as medians and inter quartile ranges and compared using non-parametric tests (Altman, 1999). When these variables were used in the different models, the homogeneity of variance and normal distribution of residuals were checked (Field, 2009). It was shown that the residuals of the variable MOV during the night were not normally distributed and were thus logarithmically transformed before being used in the multiple regression analysis.

The skin temperature increased during the measurement in the pilot study (Study II), which resulted in the skin temperature not being equal in the different positions. The influence that this might have on the blood flow results was handled in two ways. First, the relative change in blood flow was calculated from a baseline period close to each new position instead of calculating the relative change from one single baseline period from the beginning of the procedure. Second, the skin temperature was used as a covariate in the ANCOVA model 1 to adjust for these differences. In the main study (Study III), the design was adjusted so that every measurement was performed on different occasions and thus under equal conditions.

Multiple testing increases the risk for type I error where we would obtain a significant difference when in fact there was no difference. Therefore, in 
comparing different positions the Sidak correction (Study II), Bonferroni test (Studies II \& III), or Tukey's test (Study I) was used in the post hoc test to control the type I error rate (Field, 2009).

The division between the PIV and the non-PIV group was based upon the LDF data and median blood flow values over or below the baseline. The appropriateness of doing so was based on the literature. Previous studies of PIV have used LDF, and by using the same measurement technique the results are easier to compare (Abraham et al., 2001; B. Fromy et al., 2010; Koïtka et al., 2004). The baseline threshold was chosen based on a previous study by Sanada et al. (1997) who showed that patients who had an inability to increase blood flow over baseline values during long pressure exposures were the ones who tended to develop pressure ulcers.

\section{Transferability}

Because the aim of this thesis was to describe and evaluate how repositioning procedures work in practice, and to compare the effects on tissue blood flow in different positions, in an elderly fragile patient population, a convenience sampling was found to be most appropriate. This was further motivated by the difficulty in finding patients who were able to participate and who also met the inclusion criteria. However, the distribution of gender, age, pressure ulcer prevalence, and prevention interventions found in Study I is in congruence with national surveys from corresponding years (SALAR 2014, Båăth 2014). The patients in the studies all had several medications, comorbidities, and various pressure ulcer risk, which was also in congruence with an elderly patient population in general. The samples in the studies are, therefore, considered to be representative of an elderly patient population and might thus be transferable to this population in nursing homes and hospital wards.

It could be argued that the sample sizes in the different studies are small and that limits the transferability of our results. However, the Study I generated a large amount of data; The 52 patients included in the study generated 223 twelve-hour periods and 781 nursing staff-induced repositionings, and the 25 participants in Study III was found to be sufficient based on a power estimation.

Transferability of the findings to other patient populations and care settings is however limited. The MOV and REP data in Study I might not be equal among dependent patients living in their own residence or among patients in intensive care units. The blood flow responses in the different positions in 
Studies II-IV might be different in younger and/or paraplegic populations mainly due to differences in tissue stiffness and muscle mass proportions (Linder-Ganz et al., 2008). Furthermore, the measurements in Studies II-IV were performed on a pressure-redistribution mattress. Therefore, the findings from these studies must be interpreted with caution if the patient is nursed on other types of mattresses.

\section{Clinical applications}

Study I shows that within a group of elderly, immobilised patients who are at risk for pressure ulcer development, there exists a sub-group that cannot make minor movements by themselves. For the nursing staff, it is of particular importance to identify these patients because they very likely need more intensive repositioning interventions than others. Patients prescribed psycholeptics seems to need to be repositioned more frequently than others. The time spent in the $0^{\circ}$ supine position may needs to be taken into consideration because the patients might have difficulties in making minor movements on their own in this position. The results further suggest that it is important to treat the patient's pain adequately to increase their ability to perform minor movements on their own.

It was shown in Study I that the time intervals between repositioning could be very long. This highlights the importance of having a structured approach that ensures that the patients are repositioned within specified time intervals, even if the repositionings are individualised. For this purpose, notes, alarms, signs, etc. are valuable to use as reminders for the nursing staff. In the future, a device such as the MiS, with the alarm function turned on, might be a helpful tool both to identify those patients who cannot make minor movements and to guide the nursing staff in decision-making regarding repositioning frequencies and positions used. Because repositioning requires nursing staff efforts, a device such as the MiS has the potential to improve clinical effectiveness by allowing nursing staff to target interventions where they are most needed.

The $30^{\circ}$ supine tilt position was the most beneficial position (Studies II and III) from a tissue perfusion perspective and might thus be a valuable position to use in a repositioning schedule. This position might be of extra value to use during the nighttime because this position can be obtained without necessarily "turning" the patient and thus might not interrupt the patient's sleep. However, 
caution must be taken regarding the heels because they are not relieved from pressure in this position.

Although the pressure was significantly higher in the $90^{\circ}$ lateral position than in the $30^{\circ}$ lateral position, the blood flow was similar or even higher in the $90^{\circ}$ lateral position than in the recommended $30^{\circ}$ lateral position. This questions the appropriateness of the recommendation to avoid the $90^{\circ}$ lateral position because this position might be beneficial for other reasons than pressure ulcer prevention. Furthermore, many individuals prefer to rest and sleep in the $90^{\circ}$ lateral position (De Koninck et al., 1992), and this must also be considered.

Study IV showed that the elderly patients with non-PIV response had this lack of response during almost the entire time of loading. Furthermore, the PIV response was absent even when resting on a pressure-redistributing mattress. This implies that in addition to a support surface they very likely need more intensive repositioning interventions.

The MOV frequency was not related to the patient's total RAPS score. This is an important finding because it implies that immobile patients assessed as low risk might need to be repositioned as often as patients assessed as high risk. These findings highlight the importance of interpreting the risk assessment in conjunction with clinical judgment and skin assessment (Coleman et al., 2014; NPUAP et al., 2014). Regular skin assessment is particularly important to ensure that early signs of pressure ulcers are detected. If such signs are found, it will be necessary to adjust the patient's positions and/or frequency of repositioning. 


\section{Future research}

This thesis has generated several new questions for future research:

- Evaluate if a system for monitoring bodily movements can be a helpful tool in the decision-making process with regard to planning repositioning frequencies and the positions used.

- Explore the relationship between immobile patients' spontaneous movements and the incidence of pressure ulcers in the context of current nursing practice.

- Although the $30^{\circ}$ supine tilt position was shown to be most beneficial, further research is needed to evaluate if this position can be adopted by the patients and how this position can best be combined with other positions.

- Evaluate how the tissue is affected in different semi-Fowler positions because these are commonly used in practice and are beneficial for other purposes than pressure ulcer prevention.

- Explore the relationship between factors associated to blood flow responses, found in Study III, and lack of PIV response.

- Although this thesis gives indirect evidence that the tissue blood flow is similarly affected in both the $30^{\circ}$ lateral and $90^{\circ}$ lateral positions, further studies are needed to confirm the true effect of adopting these positions. 


\section{CONCLUSIONS}

- Although elderly and immobilised, some patients frequently reposition themselves while others do not. The patients who cannot make minor movements are especially important to identify because they very likely need more intensive repositioning interventions than others.

- Analgesics were shown to be positively related and psycholeptics negatively related to the patients' spontaneous movement frequency.

- The spontaneous movement frequency was not associated with the total risk assessment score, which implies that some immobile patients assessed as low risk might need to be repositioned as often as patients assessed as high risk.

- The design and procedure for blood flow comparison between positions worked well.

- Of the positions evaluated, the $30^{\circ}$ supine tilt position was shown to be the most beneficial position with regard to tissue blood flow.

- The pressure was significantly higher in the $90^{\circ}$ lateral position than in the $30^{\circ}$ lateral position, but the blood flow was similar or even higher in the $90^{\circ}$ lateral position than in the recommended $30^{\circ}$ lateral position. This question the appropriateness of the recommendation to avoid the $90^{\circ}$ lateral, because this position might be beneficial for other reasons than pressure ulcer prevention.

- The cutaneous blood flow response among the elderly patients was distinct, appeared early, and remained during the 60 minutes of loading in both the PIV and non-PIV group.

- Several factors were related to the patients overall blood flow response, but non of them were significant when comparing them between the PIV and non-PIV group. This might be due to a small sample size, and this calls for further research. 



\section{SVENSK SAMMANFATTNING}

Trycksår orsakar stort lidande för patienten och höga kostnader för samhället. Studier har visat att trycksår påverkar patienten både fysiskt, mentalt, emotionellt och socialt. Trycksår kan i de allra flesta fall förebyggas och betraktas enligt svensk patientsäkerhetslag som en vårdskada. Denna typ av skada kan uppkomma i alla situationer där en individ utsätts för mekanisk belastning, men de stora riskgrupperna för att utveckla trycksår är de patienter som är immobila och/eller är äldre och multipelt sjuka. Flertalet strategier har utvecklats för att förebygga trycksår där en bedömning av patientens risk att utveckla trycksår är steg ett. Utifrån riskbedömningen planeras sedan förebyggande insatser där regelbunden lägesändring, tillsammans med tryckavlastande dynor och madrasser, är en rekommenderad och ofta använd åtgärd. Vi vet dock väldigt lite om hur denna åtgärd utförs i vården och det $\mathrm{i}$ förhållande till patientens egen förmåga att göra mindre rörelser själv. Olika positioner används också i ett så kallat vändschema, men det saknas evidens för vilka positioner som kan rekommenderas.

Det övergripande syftet med denna avhandling var därför att beskriva och utvärdera hur regelbunden lägesändring fungerar i den dagliga vården av äldre immobila patienter. Vidare var syftet att jämföra hur olika positioner påverkar blodflödet i vävnaden, i relation till tryck och hudtemperatur, när äldre patienter ligger i en säng med tryckförebyggande madrass.

Avhandlingen består av fyra kvantitativa studier. I Studie I inkluderades 62 äldre immobila patienter. Varje patient deltog tre dygn och under den tiden registrerades patientens rörelser med hjälp av en dosa (MovinSense). Under samma period noterade personalen i ett protokoll varje gång de hjälpte patienten att ändra läge. Personalens noteringar jämfördes med de rörelser som dosan registrerat och på så sätt kunde patientens spontana rörelser urskiljas. Studie II var en pilotstudie där 20 äldre sjukhuspatienter inkluderades. Blodflöde och hudtemperatur mättes under 5 min över ländrygg, höft och sätesmuskel i sex olika sänglägespositioner. I denna studie mättes blodflödet med fotopletysmografi (PPG) som är en icke-invasiv optisk mätmetod. Pilotstudien ledde fram till studie III, och en ny grupp av patienter inkluderades $(n=25)$, men denna gång från tre äldreboenden. Några justeringar gjordes utifrån pilotstudien; mätning av tryck lades till, Laser-Doppler Flowmetry (LDF) lades till som optisk mätmetod, mättiden utökades från 5 minuter till 1 
timma, mätningarna över sätesmuskeln exkluderades, och antalet positioner som utvärderades minskades ner från sex till fyra. I Studie IV gjordes en djupare analys av blodflödessvaren som framkom i Studie III, och deltagarna delades upp i två grupper; de som hade tryckinducerad vasodilatering (PIV) och de som inte hade denna blodflödes respons (non-PIV).

Resultatet i Studie I visade att det var stor variation i vilken grad patienterna klarade av att göra mindre lägesändringar själva, och denna rörelseförmåga var främst relaterad till två stycken läkemedelsgrupper; positivt relaterad till smärtstillande läkemedel och negativt relaterad till lugnande medel/ sömnmedel. Det var också många faktorer som var relaterade till hur ofta personalen vände patienterna, och av dem hade riskbedömningspoängen störst betydelse. Patienter som hade hög risk för trycksår vändes oftare än patienter med låg risk, men patientens förmåga att göra mindre lägesjusteringar själv var inte relaterad till risknivån. Pilotstudien (Studie II) visade att designen och proceduren fungerade bra att det verkade finnas skillnader mellan hur blodflödet påverkas i de olika positionerna. Studie III visade att det totala blodflödet var högst i $30^{\circ}$ tiltat ryggläge, jämfört med de övriga positionerna $0^{\circ}$ ryggläge, $90^{\circ}$ sidoläge och $30^{\circ}$ sidoläge. Trots att trycket var signifikant högre i $90^{\circ}$ sidoläge jämfört med $30^{\circ}$ sidoläge, var blodflödet i $90^{\circ}$ sidoläge lika eller till och med högre än i den mer rekommenderade $30^{\circ}$ sidolägespositionen. I både Studie II och Studie III, visade det sig att det vanligaste blodflödessvaret på gruppnivå var ett ökat blodflöde, men vid djupare analys framkom det att hos non-PIV gruppen sjönk blodflödet nästan direkt vid belastning och var sedan fortsatt lågt under hela mättiden (Studie IV).

Avhandlingen visar att det inom patientgruppen immobila sköra äldre finns en sub-grupp som inte klarar av att göra mindre lägesjusteringar själva. Dessa är viktiga att kunna identifiera, då de troligen behöver lägesändras oftare än andra. Avhandlingen visar också att även patienter som bedöms ha låg risk för trycksår kan behöva lägesändras lika ofta som högriskpatienter. Av de positioner som utvärderades visade sig $30^{\circ}$ tiltat ryggläge vara mest fördelaktig. Denna position kan vara av extra värde att använda nattetid, då den går att få till utan att nödvändigtvis vända patienten. Blodflödet påverkades likvärdigt i både $30^{\circ}$ sidoläge och $90^{\circ}$ sidoläge, vilket ifrågasätter rekommendationen att undvika $90^{\circ}$ sidoläge, särskilt med tanke på att $90^{\circ}$ sidläge kan vara viktig ur andra aspekter än trycksårprevention. Patienter som saknar en normal PIVfunktion är särskilt sårbara och behöver troligen också lägesändras oftare än andra. Fortsatta studier behövs dock för att finna faktorer som kan prediktera dessa patienter. 


\section{ACKNOWLEDGEMENTS}

I would like to express my sincere gratitude to all who have supported me in different ways in the completion of this thesis. Special thanks to:

All participants in the studies for giving of your time. Many life stories have been entrusted to me, thank you!

Margareta Lindgren, my main supervisor, for your scientific guidance, constructive criticism, encouragement and positive attitude, and for inspiring me to become a researcher.

Anna-Christina Ek, my co-supervisor, for believing in me and generously sharing your great scientific knowledge and enthusiasm for pressure ulcer research.

Maria Engström, my co-supervisor, for always being supportive and giving valuable scientific advice and constructive criticisms.

Sara Bergstrand, co-author and research colleague, for generously sharing your knowledge and skills. Thanks for all fruitful discussions, funny and pleasant moments during the way and for being a true friend.

Mats Fredrikson, co-author, for excellent statistical advices and stimulating discussions.

Lars-Göran Lindberg, co-author, for giving me valuable technical assistance and knowledge on blood flow measurements and analysis, and to Bengt Ragnemalm, research engineer at IMT, for providing prompt and excellent technical support.

Pedro Silva and Willem Oomen at Kinematix for valuable technical support regarding the MovinSense system.

Anita Danielsson, for your valuable assistance during the measurements performed in Linköping. Thanks for the good cooperation and for your engagement and friendship. 
To all senior lectures, doctoral students, and others at the Department of Medical and Health Sciences, Division of Nursing Sciences, for all the valuable discussions, friendships and help.

To my current and former managers Ulrica Östlund, Anna Hagborg, Pia Sigfridsson and Lars Arenlind at the Dermatology Department, South Älvsborg Hospital, for being supportive. To all my colleagues at the department, for all your support and interest in my research. Special thanks to Kerstin Bobeck, for your encouragement and enthusiasm, and for being my photo model.

To all my colleagues at the Research unit at South Älvsborg Hospital, for practical support, fruitful discussions and joyful moments. Special thanks to Zeina Zimmerman, Anneli Schwartz and Marie Rusner.

To Bengt-Arne Andersson, former colleague at Äldre Väst Sjuhärad, who recognised my research interest and helped me to take the first step of this journey. Thanks for being a true friend and an excellent training partner.

To my dear friend Monica Jaxelius for your support in English in the beginning and for being just who you are!

To my parents Anna-Christina \& Roland Löfström for loving me and caring about me and my family, and for all your help with practical issues.

And last, but not least, to my beloved family Lennart, Oscar and Eric - you are my joy and strength in life! Thanks for the never-ending support, patience and love. I look forward to new adventures together!

\section{Thanks to you all! / Ubrika}

Financial support was granted by: the Swedish Research Council, the Research Council Södra Älvsborg, the Research Council Östergötland, the Dermatology department Research Foundation at Södra Älvsborg Hospital, the SwedBank Sjuhärad foundation for research at the Södra Älvsborg Hospial, the Södra Älvsborgs Hospital, the King Gustaf V and Queen Victoria's Freemason Foundation, the NovaMedTech and European Union-European Regional Development Fund, and the Faculty of Health Science at Linköping Unviersity. 


\section{REFERENCES}

Abraham, P., Fromy, B., Merzeau, S., Jardel, A., \& Saumet, J. L. (2001). Dynamics of local pressure-induced cutaneous vasodilation in the human hand. Microvascular Research, 61(1), 122-129.

Allen, J. (2007). Photoplethysmography and its application in clinical physiological measurement. Physiological Measurement, 28(3), 1-39.

Altman, D. (1999). Practical statistics for medical research. London: Chapman \& Hall/CRC.

Baumgarten, M., Margolis, D. J., Localio, A. R., Kagan, S. H., Lowe, R. A., Kinosian, B., Holmes, H., Abbuhl, B., Kavash, W., \& Ruffin, A. (2006). Pressure ulcers among elderly patients early in the hospital stay. Journals of Gerontology - Series A Biological Sciences and Medical Sciences, 61(7), 749754.

Bennett, G., Dealey, C., \& Posnett, J. (2004). The cost of pressure ulcers in the UK. Age and Ageing, 33(3), 230-235.

Bennett, L., Kavner, D., \& Lee, B. Y. (1981). Skin blood flow in seated geriatric patients. Archives of Physical Medicine and Rehabilitation, 62(8), 392-398.

Bergstrand, S. (2014). Preventing pressure ulcers by assessment of the microcirculation in tissue exposed to pressure. Medical Dissertations No 1407, Linköping: Linköping University.

Bergstrand, S., Källman, U., Ek, A. C., Lindberg, L. G., Engström, M., Sjöberg, F., \& Lindgren, M. (2014). Pressure-induced vasodilatation and reactive hyperemia at different depths in sacral tissue under clinically relevant conditions. Microcirculation, 21(8):761-71.

Bergstrand, S., Länne, T., Ek, A. C., Lindberg, L. G., Linden, M., \& Lindgren, M. (2010). Existence of tissue blood flow in response to external pressure in the sacral region of elderly individuals - using an optical probe prototype. Microcirculation, 17(4), 311-319.

Bergstrom, N., Horn, S. D., Rapp, M. P., Stern, A., Barrett, R., \& Watkiss, M. (2013). Turning for ulcer ReductioN: A Multisite randomized clinical trial in nursing homes. Journal of the American Geriatrics Society, 61(10), 17051713.

Björstad, Å., \& Forsmark, A. (2012). Trycksår i Sverige - kunskapsöversikt och beräkning av kostnader för slutenvården. 
http://www.careofsweden.se/wpcontent/uploads/2013/10/Care Of Swe den Rapport trycksar 121220 NHE.pdf (accessed 16 apr 2015)

Bliss, M. R. (1993). Aetiology of pressure sores. Reviews in Clinical Gerontology, 3(4), 379-397.

Braverman, I. M. (1997). The cutaneous microcirculation: Ultrastructure and microanatomical organization. Microcirculation, 4(3), 329-340.

Bredesen, I. M., Bjøro, K., Gunningberg, L., \& Hofoss, D. (2015). The prevalence, prevention and multilevel variance of pressure ulcers in Norwegian hospitals: A cross-sectional study. International Journal of Nursing Studies, 52(1), 149-156.

Burk, R. S., \& Grap, M. J. (2012). Backrest position in prevention of pressure ulcers and ventilator-associated pneumonia: Conflicting recommendations. Heart and Lung: Journal of Acute and Critical Care, 41(6), 536-545.

Bååth, C., Idvall, E., Gunningberg, L., \& Hommel, A. (2014). Pressure-reducing interventions among persons with pressure ulcers: Results from the first three national pressure ulcer prevalence surveys in Sweden. Journal of Evaluation in Clinical Practice, 20(1), 58-65.

Cederholm, T. (2011). Åldrande, mat och näring. In E. Lövestam (Ed.), Vetenskapligt underlag till råd om bra mat $i$ äldreomsorgen (Vol. 3, pp. 81). Uppsala, Sweden: National Food Administration.

Chou, R., Dana, T., Bougatsos, C., Blazina, I., Starmer, A. J., Reitel, K., \& Buckley, D. I. (2013). Pressure ulcer risk assessment and prevention: a systematic comparative effectiveness review. Annals of Internal Medicine, 159(1), 2838.

Coleman, S., Gorecki, C., Nelson, E. A., Closs, S. J., Defloor, T., Halfens, R., Farrin, A., Brow, J., Schoonhoven, L. \& Nixon, J. (2013). Patient risk factors for pressure ulcer development: Systematic review. International Journal of Nursing Studies, 50(7), 974-1003.

Coleman, S., Nixon, J., Keen, J., Wilson, L., McGinnis, E., Dealey, C., Stubbs, N., Farrin, A., Dowding, D., Schols, J. M., Cuddigan, J., Berlowitz, D., Jude, E., Vowden, P., Schoonhoven, L., Bader, D. L., Gefen, A., Oomens, C. W \& Nelson, E. A. (2014). A new pressure ulcer conceptual framework. Journal of Advanced Nursing, 70(10), 2222-2234.

Colin, D., Abraham, P., Preault, L., Bregeon, C., \& Saumet, J. L. (1996). Comparison of 90 degrees and 30 degrees laterally inclined positions in the prevention of pressure ulcers using transcutaneous oxygen and carbon dioxide pressures. Advances in wound care : the journal for prevention and healing, 9(3), 35-38. 
Daly, M. J., \& Henry, R. E. (1980). Quantitative measurement of skin perfusion with Xenon-133. The journal of nuclear medicin, 21, 156-160.

De Koninck, J., Lorrain, D., \& Gagnon, P. (1992). Sleep positions and position shifts in five age groups: An ontogenetic picture. Sleep, 15(2), 143-149.

Defloor, T. (2000). The effect of position and mattress on interface pressure. Applied nursing research, 13(1), 2-11.

Dinsdale, S. (1974). Decubitus ulcers: role of pressure and friction in causation. Archives of Physical Medicine and Rehabilitation, 55(4), 147-152.

Ek, A. C., Gustavsson, G., \& Lewis, D. H. (1987). Skin blood flow in relation to external pressure and temperature in the supine position on a standard hospital mattress. Scandinavian Journal of Rehabilitation Medicine, 19(3), 121-126.

Ek, A. C., Lewis, D. H., Zetterqvist, H., \& Svensson, P. G. (1984). Skin blood flow in an area at risk for pressure sore. Scandinavian Journal of Rehabilitation Medicine, 16(2), 85-89.

Exton-Smith, A. N., \& Sherwin, R. W. (1961). The prevention of pressure sores significants of spontaneous bodily movements. The Lancet, 278(7212), 1124-1126.

Fawcett, J. (1995). Analysis and evaluation of conceptual models of nursing, 3rd Ed, Philadelphia: F. A. Davis Company.

Field, A. (2009). Discovering statistics using SPSS, 3rd Ed, London: SAGE Publications Ltd.

Filius, A., Damen, T. H., Schuijer-Maaskant, K. P., Polinder, S., Hovius, S. E., \& Walbeehm, E. T. (2013). Cost analysis of surgically treated pressure sores stage III and IV. Journal of Plastic, Reconstructive \& Aesthetic Surgery, 66(11), 1580-1586.

Fogerty, M., Abumrad, N., Nanney, L., Arbogast, P., Poulose, B., \& Barbul, A. (2008). Risk factors for pressure ulcers in acute care hospitals. Wound Repair and Regeneration, 16(1), 11-18.

Fossum, M., Alexander, G. L., Ehnfors, M., \& Ehrenberg, A. (2011). Effects of a computerized decision support system on pressure ulcers and malnutrition in nursing homes for the elderly. International Journal of Medical Informatics, 80(9), 607-617.

Frantz, R., Xakellis, G. C., \& Arteaga, M. (1993). The effects of prolonged pressure on skin blood flow in elderly patients at risk for pressure ulcers. Decubitus, 6(6), 16-20.

Fredriksson, I., Larsson, M., \& Strömberg, T. (2009). Measurement depth and volume in laser Doppler flowmetry. Microvascular Research, 78(1), 4-13. 
Fromy, B., Lingueglia, E., Sigaudo-Roussel, D., Saumet, J. L., \& Lazdunski, M. (2012). Asic3 is a neuronal mechanosensor for pressure-induced vasodilation that protects against pressure ulcers. Nature Medicine, 18(8), 1205-1207.

Fromy, B., Sigaudo-Roussel, D., Gaubert-Dahan, M. L., Rousseau, P., Abraham, P., Benzoni, D., Berrut, G. \& Saumet, J. L. (2010). Aging-associated sensory neuropathy alters pressure-induced vasodilation in humans. Journal of Investigative Dermatology, 130(3), 849-855.

Gerhardt, L. C., Lenz, A., Spencer, N. D., Munzer, T., \& Derler, S. (2009). Skintextile friction and skin elasticity in young and aged persons. Skin Research and Technology, 15(3), 288-298.

Giles, T. D., Sander, G. E., Nossaman, B. D., \& Kadowitz, P. J. (2012). Impaired vasodilation in the pathogenesis of hypertension: focus on nitric oxide, endothelial-derived hyperpolarizing factors, and prostaglandins. Jorunal of Clinical Hypertension, 14(4), 198-205.

Gillespie, B. M., Chaboyer, W. P., McInnes, E., Kent, B., Whitty, J. A., \& Thalib, L. (2014). Repositioning for pressure ulcer prevention in adults. Cochrane Database Systemic Review, 4, 1-35.

Gorecki, C., Brown, J. M., Nelson, E. A., Briggs, M., Schoonhoven, L., Dealey, C., Defloor, T. \& Nixon, J. (2009). Impact of pressure ulcers on quality of life in older patients: A systematic review: Clinical investigations. Journal of the American Geriatrics Society, 57(7), 1175-1183.

Gunningberg, L., Carlsson, S., \& Willman, A. (2006). EPUAP-protocol - a European method to survey pressure ulcers (in Swedish). Varrd $i$ norden, 26(2), 48-51.

Guyton, A. C., \& Hall, J. E. (2011). Guyton and Hall: textbook of medical physiology, 12th Ed, Philadelphia: Saunders/Elsevier.

Hagblad, J. (2011). Non-invasive techniques for assessment of peripheral blood flow at different vascular depths. Licentiate Thesis, Västerås: Mälardalen University.

Hagblad, J., Folke, M., Lindberg, L. G., \& Lindén, M. (2012). Technical issues related to the long-term monitoring of blood flow at different depths using LDF and PPG. Physiological Measurement, 33(6), 985-996.

Hagblad, J., Lindberg, L. G., Andersson, A. K., Bergstrand, S., Lindgren, M., Ek, A. C., Folke, M. \& Lindén, M. (2010). A technique based on laser Doppler flowmetry and photoplethysmography for simultaneously monitoring blood flow at different tissue depths. Medical and Biological Engineering and Computing, 48(5), 415-422. 
Harada, C., Shigematsu, T., \& Hagisawa, S. (2002). The effect of 10-degree leg elevation and 30-degree head elevation on body displacement and sacral interface pressures over a 2-hour period. Journal of Wound, Ostomy and Continence Nursing, 29(3), 143-148.

Hawkins, S., Stone, K., \& Plummer, L. (1999). An holistic approach to turning patients. Nursing standard, 14(3), 51-56.

Hodges, G. J., Nawaz, S., \& Tew, G. A. (2014). Evidence that reduced nitric oxide signal contributes to cutaneous microvascular dysfunction in peripheral arterial disease. Clinical Hemorheology and Microcirculation, 59(1):83-95.

Hopkins, A., Dealey, C., Bale, S., Defloor, T., \& Worboys, F. (2006). Patient stories of living with a pressure ulcer. Journal of Advanced Nursing, 56(4), 345-353.

Humeau, A., Steenbergen, W., Nilsson, H., \& Strömberg, T. (2007). Laser Doppler perfusion monitoring and imaging: Novel approaches. Medical and Biological Engineering and Computing, 45(5), 421-435.

Johansen, E., Moore, Z., Van Etten, M., \& Strapp, H. (2014). Pressure ulcer risk assessment and prevention: What difference does a risk scale make? A comparison between Norway and Ireland. Journal of Wound Care, 23(7), 369-378.

Johansson, L., Hägg, M., \& Fischer, T. (2002). Skin blood flow in the human hand in relation to applied pressure. European Journal of Applied Physiology, 86(5), 394-400.

Johnson, J. M., Minson, C. T., \& Kellogg, D. L., Jr. (2014). Cutaneous vasodilator and vasoconstrictor mechanisms in temperature regulation. Comprehensive Physiology, 4(1), 33-89.

Jonsson, P. (2008). Overview of the microcirculation. In Tuna, D. (Ed.), Microcirculation, Sandiego: Elsevier Inc/Academic Press.

Kamel, N. S., \& Gammack, J. K. (2006). Insomnia in the Elderly: Cause, Approach, and Treatment. The American Journal of Medicine, 119(6), 463469.

Kasuya, A., Sakabe, J., \& Tokura, Y. (2014). Potential application of in vivo imaging of impaired lymphatic duct to evaluate the severity of pressure ulcer in mouse model. Scientific Reports, 4, 4173.

Koïtka, A., Abraham, P., Bouhanick, B., Sigaudo-Roussel, D., Demiot, C., \& Saumet, J. L. (2004). Impaired Pressure-Induced Vasodilation at the Foot in Young Adults with Type 1 Diabetes. Diabetes, 53(3), 721-725.

Kosiak, M. (1959). Etiology and Pathology of Ischemic Ulcers. Archive of Physiological Medicine and Rehabilitation, 40, 62-68. 
Kottner, J., Dassen, T., \& Lahmann, N. (2010). Prevalence of deep tissue injuries in hospitals and nursing homes: two cross-sectional studies. International Jorunal of Nursing Studies, 47(6), 665-670.

Kutner, M., Nachtsheim, C., Neter, J., \& Li, W. (2004). Applied Linear Statistical Models, 5th Ed, New York: McGraw-Hill Higher Education.

Källman, U., \& Lindgren, M. (2014). Predictive validity of 4 risk assessment scales for prediction of pressure ulcer development in a hospital setting. Advances in skin and wound care, 27(2), 70-76.

Källman, U., \& Suserud, B. O. (2009). Knowledge, attitudes and practice among nursing staff concerning pressure ulcer prevention and treatment - A survey in a Swedish healthcare setting. Scandinavian journal of caring sciences, 23(2), 334-341.

Lachenbruch, C., Tzen, Y. T., Brienza, D., Karg, P. E., \& Lachenbruch, P. A. (2015). Relative contributions of interface pressure, shear stress, and temperature on ischemic-induced, skin-reactive hyperemia in healthy volunteers: A repeated measures laboratory study. Ostomy Wound Manage, 61(2), 16-25.

Langemo, D. (2012). General principles and approaches to wound prevention and care at end of life: an overview. Ostomy Wound Manage, 58(5), 24-26, 28, 30 passim.

Leopold, E., \& Gefen, A. (2013). Changes in permeability of the plasma membrane of myoblasts to fluorescent dyes with different molecular masses under sustained uniaxial stretching. Medical Engineering and Physics, 35(5), 601-607.

Lindberg, L.-G., \& Öberg, P. A. (1993). Optical properties of blood in motion. Optical Engineering, 32(2), 253-257.

Linder-Ganz, E., \& Gefen, A. (2007). The effects of pressure and shear on capillary closure in the microstructure of skeletal muscles. Annuals of Biomedichal Engineering, 35(12), 2095-2107.

Linder-Ganz, E., Shabshin, N., Itzchak, Y., Yizhar, Z., Siev-Ner, I., \& Gefen, A. (2008). Strains and stresses in sub-dermal tissues of the buttocks are greater in paraplegics than in healthy during sitting. Jorunal of Biomechanics, 41(3), 567-580.

Lindgren, M., Unosson, M., Fredrikson, M., \& Ek, A. C. (2004). Immobility - A major risk factor for development of pressure ulcers among adult hospitalized patients: A prospective study. Scandinavian journal of caring sciences, 18(1), 57-64. 
Lindgren, M., Unosson, M., Krantz, A. M., \& Ek, A. C. (2002). A risk assessment scale for the prediction of pressure sore development: Reliability and validity. Journal of Advanced Nursing, 38(2), 190-199.

Loerakker, S., Manders, E., Strijkers, G. J., Nicolay, K., Baaijens, F. P., Bader, D. L., \& Oomens, C. W. (2011). The effects of deformation, ischemia, and reperfusion on the development of muscle damage during prolonged loading. Journal of Applied Physiology, 111(4), 1168-1177.

McLellan, K., Petrofsky, J. S., Zimmerman, G., Lohman, E., Prowse, M., Schwab, E., \& Lee, S. (2009). The influence of environmental temperature on the response of the skin to local pressure: the impact of aging and diabetes. Diabetes technology \& therapeutics, 11(12), 791-798.

Moore, Z., \& Cowman, S. (2012). Pressure ulcer prevalence and prevention practices in care of the older person in the Republic of Ireland. Journal of Clinical Nursing, 21(3-4), 362-371.

Moore, Z., Cowman, S., \& Conroy, R. M. (2011). A randomised controlled clinical trial of repositioning, using the $30^{\circ}$ tilt, for the prevention of pressure ulcers. Journal of Clinical Nursing, 20(17-18), 2633-2644.

Moore, Z. E., \& Cowman, S. (2015). Repositioning for treating pressure ulcers. Cochrane database of systematic reviews, Issue 1, 1-12.

Neuman, B. (1996). The Neuman systems model in research and practice. Nursing Sciences, 9(2), 67-70.

Nola, G. T., \& Vistnes, L. M. (1980). Differential response of skin and muscle in the experimental production of pressure sores. Plastic and Reconstructive Surgery, 66(5), 728-733.

NPUAP., EPUAP., \& PPPIA. (2014). Prevention and Treatment of Pressure Ulcers: Clinical Practice Guideline. Perth : Cambridge Media.

Oomens, C. W., Loerakker, S. \& Bader, D. L. The importance of internal strain as opposed to interface pressure in the prevention of pressure related deep tissue injury. Journal of Tissue Viability 2010 May;19(2):35-42.

Pallant, J. (2010). SPSS survival manual : a step by step guide to data analysis using IBM SPSS, 4th Ed, Maidenhead: McGraw-Hill Education.

Peirce, S. M., Skalak, T. C., \& Rodeheaver, G. T. (2000). Ischemia-reperfusion injury in chronic pressure ulcer formation: A skin model in the rat. Wound Repair and Regeneration, 8(1), 68-76.

Piantadosi, S. (2005). Clinical trials: a methodologic perspective, 2nd Ed, Hoboken: John Wiley \& Sons, Inc.

Polit, D. F., \& Beck, C. T. (2010). Essentials of nursing research : appraising evidence for nursing practice, 7th Ed, Philadelphia: Wolters Kluwer Health/Lippincott. 
Poole, D. (2003). Linear algebra a modern introduction. Pacific Grove: Brooks/Cole corp.

Popcock, G., \& Richards, C. D. (2006). Human physiology - the basis of medicine, 3rd ed, New York: Oxford University Press.

Reddy, N. P., Cochran, G. V. B., \& Krouskop, T. A. (1981). Interstitial fluid flow as a factor in decubitus ulcer formation. Journal of Biomechanics, 14(12), 879-881.

Rhoades, R., \& Bell, D. (2009). Medical Physiology - priciples for clinical medicine, 3rd Ed, Philadelphia: Lippincott Williams \& Wilkins.

Rithalia, S. (2005). Assessment of patient support surfaces: Principle, practice and limitations. Journal of Medical Engineering and Technology, 29(4), 163169.

Ross, J., \& Dean, E. (1989). Integrating physiological principles into the comprehensive management of cardiopulmonary dysfunction. Physical Therapy, 69(4), 255-259.

Rossi, M., Cupisti, A., Ricco, R., Santoro, G., Pentimone, F., \& Carpi, A. (2004). Skin vasoreactivity to insulin iontophoresis is reduced in elderly subjects and is absent in treated non-insulin-dependent diabetes patients. Biomedicine and Pharmacotherapy, 58(10), 560-565.

Roustit, M., \& Cracowski, J. L. (2013). Assessment of endothelial and neurovascular function in human skin microcirculation. Trends in Pharmacological Sciences, 34(7), 373-384.

Ryan, T. (1991). Cutaneous circulation. In L. Goldsmith (Ed.), Physiology, biochemistry, and molecular biology of the skin (2th ed., Vol. II, pp. 1019-1084). New York: Oxford University Press.

Sanada, H., Nagakawa, T., Yamamoto, M., Higashidani, K., Tsuru, H., \& Sugama, J. (1997). The role of skin blood flow in pressure ulcer development during surgery. Advances in wound care, 10(6), 29-34.

SALAR (204). Förebyggande åtgärder mot trycksår ökat något. Swedish Association of Local Authorities and Regions. http://skl.se/halsasjukvard/patientsakerhet/matningavskadorivarden/ma tningavtrycksar/resultattrycksar.2125.html (accessed 16 apr 2015).

Schubert, V., \& Fagrell, B. (1989). Local skin pressure and its effect on skin microcirculation as evaluated by laser-Doppler fluxmetry. Clinical Physiology, 9(6), 535-545.

Schubert, V., \& Heraud, J. (1994). The effects of pressure and shear on skin microcirculation in elderly stroke patients lying in supine or semirecumbent positions. Age and Ageing, 23(5), 405-410. 
Schuurman, J. P., Schoonhoven, L., Defloor, T., Van Engelshoven, I., Van Ramshorst, B., \& Buskens, E. (2009). Economic evaluation of pressure ulcer care: A cost minimization analysis of preventive startegies. Nursing Economics, 27(6), 390-400, 415.

Seiler, W. O., Allen, S., \& Stähelin, H. B. (1986). Influence of the $30^{\circ}$ laterally inclined position and the 'super-soft' 3-piece mattress on skin oxygen tension on areas of maximum pressure. Implications for pressure sore prevention. Gerontology, 32(3), 158-166.

Seiler, W. O., \& Stähelin, H. B. (1986). Recent findings on decubitus ulcer pathology: Implications for care. Geriatrics, 41(1), 47-50, 53-57, 60.

Shoham, N., \& Gefen, A. (2012). Deformations, mechanical strains and stresses across the different hierarchical scales in weight-bearing soft tissues. Journal of tissue viability, 21(2), 39-46.

Singer, C. M., \& Applebee, G. A. (2008). Sleep disorders, In F. Christensen (Ed.) Behavioral Medicine: A Guide for Clinical Practice, 3rd Ed, New York: McGraw-Hill.

Sonksen, J., \& Craggs, J. (1999). Circulation of the skin. Current Anaesthesia and Critical Care, 10(2), 58-63.

Spilsbury, K., Nelson, A., Cullum, N., Iglesias, C., Nixon, J., \& Mason, S. (2007). Pressure ulcers and their treatment and effects on quality of life: Hospital inpatient perspectives. Journal of Advanced Nursing, 57(5), 494-504.

Sprigle, S., \& Sonenblum, S. (2011). Assessing evidence supporting redistribution of pressure for pressure ulcer prevention: a review. Journal of Rehabilitation Research and Development, 48(3), 203-213.

Stansberry, K. B., Hill, M. A., Shapiro, S. A., McNitt, P. M., Bhatt, B. A., \& Vinik, A. I. (1997). Impairment of peripheral blood flow responses in diabetes resembles an enhanced aging effect. Diabetes Care, 20(11), 1711-1716.

Stekelenburg, A., Gawlitta, D., Bader, D. L., \& Oomens, C. W. (2008). Deep Tissue Injury: How Deep is Our Understanding? Archives of Physical Medicine and Rehabilitation, 89(7), 1410-1413.

Stephen-Haynes, J. (2012). Pressure ulceration and palliative care: prevention, treatment, policy and outcomes. International Journal of Palliative Nursing, 18(1), 9-16.

Sving, E., Idvall, E., Högberg, H., \& Gunningberg, L. (2014). Factors contributing to evidence-based pressure ulcer prevention. A cross-sectional study. International Journal of Nursing Studies, 51(5), 717-725.

Tescher, A. N., Branda, M. E., Byrne, T. J. O., \& Naessens, J. M. (2012). All at-risk patients are not created equal: Analysis of braden pressure ulcer risk 
scores to identify specific risks. Journal of Wound, Ostomy and Continence Nursing, 39(3), 282-291.

Vanderwee, K., Clark, M., Dealey, C., Gunningberg, L., \& Defloor, T. (2007). Pressure ulcer prevalence in Europe: a pilot study. Journal of Evaluation in Clinical Practice, 13(2), 227-235.

Vanderwee, K., Defloor, T., Beeckman, D., Demarre, L., Verhaeghe, S., Van Durme, T., \& Gobert, M. (2011). Assessing the adequacy of pressure ulcer prevention in hospitals: a nationwide prevalence survey. BMJ Quality and Safety, 20(3), 260-267.

Vanderwee, K., Grypdonck, M. H., De Bacquer, D., \& Defloor, T. (2007). Effectiveness of turning with unequal time intervals on the incidence of pressure ulcer lesions. Journal of Advanced Nursing, 57(1), 59-68.

Witkowski, J. A., \& Parish, L. (1982). Histopathology of the decubitus ulcer. Journal of the American Academy of Dermatology, 6(6), 1014-1021.

WMA. (2008). World Medical Association Declaration of Helsinki. Ethical principles for medical research involving human subject. http://www.wma.net/en/30publications/10policies/b3/index.html (accessed 16 apr 2015).

Won, A., Lapane, K. L., Vallow, S., Schein, J., Morris, J. N., \& Lipsitz, L. A. (2006). Long-term effects of analgesics in a population of elderly nursing home residents with persistent nonmalignant pain. Journals of Gerontology Series A Biological Sciences and Medical Sciences, 61(2), 165-169.

Voz, A., Williams, C., \& Wilson, M. (2011). Who is turning the patients? A survey study, Journal of Wound Ostomy Continence Nursing, 38(4), 413-418. Wywialowski, E. F. (1999). Tissue perfusion as a key underlying concept of pressure ulcer development and treatment. Jorunal of Vascular Nursing, 17(1), 12-16.

Young, T. (2004). The 30 degree tilt position vs the 90 degree lateral and supine positions in reducing the incidence of non-blanching erythema in a hospital inpatient population: a randomised controlled trial. Journal of tissue viability, 14(3), 88, 90, 92-96.

Zhang, Q., Lindberg, L-G., Kadefors R., Styf, J. (2001). A non-invasice measure of changes in blood flow in the human anterior tibial muscle. European Journal of Applied Physiology, 84, 448-452. 


\section{Papers}

The articles associated with this thesis have been removed for copyright reasons. For more details about these see:

http://urn.kb.se/resolve?urn=urn:nbn:se:liu:diva-117447 